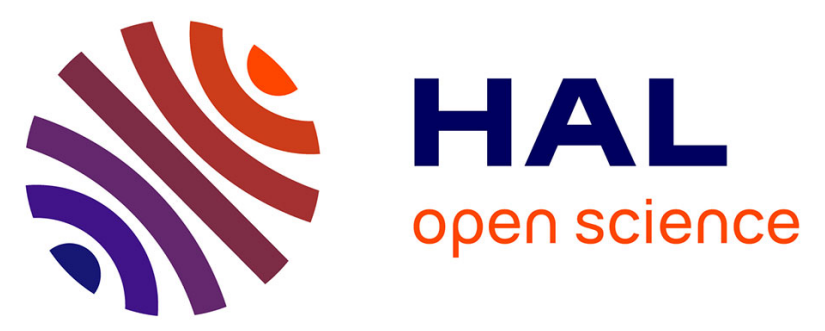

\title{
Chemoenzymatic Synthesis of Glycoconjugates Mediated by Regioselective Enzymatic Hydrolysis of Acetylated 2-Amino Pyranose Derivatives
}

Changping Zheng, Teodora Bavaro, Sara Tengattini, Andrea Gualla Mascherpa, Matthieu Sollogoub, Yongmin Zhang, Marco Terreni

\section{To cite this version:}

Changping Zheng, Teodora Bavaro, Sara Tengattini, Andrea Gualla Mascherpa, Matthieu Sollogoub, et al.. Chemoenzymatic Synthesis of Glycoconjugates Mediated by Regioselective Enzymatic Hydrolysis of Acetylated 2-Amino Pyranose Derivatives. European Journal of Organic Chemistry, 2019, 2019 (22), pp.3622-3631. 10.1002/ejoc.201900382 . hal-02180805

\section{HAL Id: hal-02180805 \\ https://hal.sorbonne-universite.fr/hal-02180805}

Submitted on 11 Jul 2019

HAL is a multi-disciplinary open access archive for the deposit and dissemination of scientific research documents, whether they are published or not. The documents may come from teaching and research institutions in France or abroad, or from public or private research centers.
L'archive ouverte pluridisciplinaire HAL, est destinée au dépôt et à la diffusion de documents scientifiques de niveau recherche, publiés ou non, émanant des établissements d'enseignement et de recherche français ou étrangers, des laboratoires publics ou privés. 


\section{Chemoenzymatic Synthesis of Glycoconjugates Mediated by}

Regioselective Enzymatic Hydrolysis of Acetylated 2-Amino Pyranose

\section{Derivatives}

Changping Zheng, ${ }^{[a, \S]}$ Teodora Bavaro, ${ }^{[b, \S]}$ Sara Tengattini, ${ }^{[b]}$ Andrea Gualla Mascherpa, ${ }^{[c]}$ Matthieu Sollogoub, ${ }^{[\mathrm{a}]}$ Yongmin Zhang, ${ }^{*[\mathrm{a}, \mathrm{d}]}$ and Marco Terreni ${ }^{[\mathrm{b}]}$

[a] CNRS, UMR 8232, IPCM, Sorbonne Université, 4 Place Jussieu, 75005 Paris, France. yongmin.zhang@upmc.fr

[b] Drug Sciences Department, University of Pavia, Viale Taramelli 12, 27100 Pavia, Italy. marco.terreni@unipv.it

[c] School of Physical and Chemical Sciences, University of Canterbury, Private Bag 4800, 8140 Christchurch, New Zealand.

[d] Institute for Interdisciplinary Research, Jianghan University, Wuhan Economic and Technological Development Zone, 430056 Wuhan, China.

${ }^{\S}$ These two authors contributed equally to this work. 


\begin{abstract}
Highly regioselective deprotection of a series of 2-amino pyranose building blocks was achieved by enzymatic hydrolysis. These monodeprotected intermediates were successfully used in the synthesis of a variety of glycoconjugated derivatives with a core of glucosamine or galactosamine, including neo-glycoproteins and glycosphingolipids. The hydrolysis catalyzed by Acetyl xylan esterase from Bacillus pumilus (AXE) is suitable for the synthesis of neo-glycoproteins with an $N$-acetyl glucosamine core. The hydrolysis catalyzed by Candida rugosa lipase (CRL) was successfully applied in the preparation of new sialylated glycolipids starting from glucosamine building blocks protected as phthalimide. This chemoenzymatic approach can be used for the preparation of new glycoconjugated products with anticancer activity.
\end{abstract}

\title{
Introduction
}

Glycoproteins and glycolipids are involved in many physiological and pathological processes. ${ }^{[1]}$ Consequently, synthetic non-natural glycoconjugates are largely investigated for developing new therapeutic strategies, ${ }^{[2]}$ including the use of glycolipids with anticancer activity ${ }^{[3]}$ or carbohydratebased vaccines. ${ }^{[4-7]}$

In particular, sialylated oligosaccharides are involved in cell-cell adhesion processes ${ }^{[8]}$ and many of these oligosaccharides are considered as tumor associated carbohydrate antigens (TACAs) because overexpressed in cancer cells. Specific glycosphingolipid types, which are detectable in normal cells, are more highly expressed in tumors. The high level of expression on the surface of tumour cells causes an antibody response towards these glycosphingolipids, which are therefore considered as targets for cancer therapy ${ }^{[9]}$. For example the lactosyl-ganglioside GM3 (NeuAc $\alpha 3$ Gal $\beta 4$ Glc $\beta 1$ Cer), is recognized as an important melanoma-associated antigen, and may have a role in metastasis. ${ }^{[10,11]}$ Similarly, Sialyl$\mathrm{Le}^{\mathrm{X}}$, sialyl- $\alpha-1,6$-galactosamine (Sialyl-Tn antigen), and other sialylated TACAs with a core of $N$-acetyl glucosamine or galactosamine, are over-expressed in a wide variety of human cancers. ${ }^{[12]}$ 
Glycoconjugated lipid analogues of GM3, obtained by sialylation of glucose at C-6, recently have been reported as a new class of potential anticancer agents. ${ }^{[3]}$ Semi-synthetic glycoproteins (neoglycoproteins) can instead provide immunogens from which therapeutic agents can be derived. ${ }^{[13,14]}$ In particular, neo-glycoproteins have been largely investigated as therapeutic anticancer vaccines ${ }^{[15,16]}$ based on TACAs. Sialyl-Tn has been proposed as therapeutic vaccine against prostate cancer, and its assembly with other TACAs has been proposed for developing multivalent glycoconjugate vaccines. ${ }^{[17]}$ However, the study of glycoconjugates is limited by the complex procedures required for the preparation of protected building blocks bearing free hydroxyl groups in the desired positions. In presence of glucosamine or galactosamine, the synthesis of oligosaccharides is currently performed protecting the amino as acetyl-amide ${ }^{[18,19]}$ as naturally existing in the TACAs structure. However, protection as phthalimide is often preferred. ${ }^{[20]}$ At the anomeric position of the acceptor, different groups can be used, including thio-alkyl/aryl leaving groups, because after glycosylation of the free hydroxyl group, these products can be used as sugar donors for a further glycosylation reaction. ${ }^{[21]}$ In addition, for the synthesis of neo-glycoproteins should be done the preparation of building blocks with an appropriate reactive linker at anomeric position, required for conjugation with the protein carrier. One of the most used strategies implies the use of 2-iminomethoxyethyl thioglycosides (IME) that selectively reacts with lysines on the protein surface.

The use of enzymatic regioselective hydrolysis of peracetylated sugar has been proposed as an important tool for developing simple and efficient synthesis of sugar building blocks. ${ }^{[22]}$ This strategy was employed for the preparation of mannopyranose glycans with the anomeric thiocyanomethyl group, that were used for protein glycosylation after activation as anomeric IME-linker. ${ }^{[23,24]}$ Peracetylated monodeprotected galactopyranoses have also been used for the preparation of sialylated glycoconjugate lipids. ${ }^{[25]}$

The most used biocatalyst for regioselective deacetylation is the lipase from Candida rugosa (CRL). However, other enzymes were also used. In particular, Acetyl xylan esterase from Bacillus pumilus 
(AXE), has been successfully employed in the preparation of advanced building blocks by regioselective deacetylation of acetylated disaccharides. ${ }^{[26]}$ The use of this chemoenzymatic approach has never been investigated for the preparation of glyco-derivatives (neo-glycoproteins and glycolipids) using TACAs with a core of glucosamine or galactosamine, such as the STn antigen. Consequently, in this work, we have studied the regioselectively enzymatic hydrolysis of 2-amino-pyranoside derivatives (Scheme 1), exploring the effect on the enzyme activity and selectivity induced by the presence of different reactive groups in anomeric position and by the protection of the 2-amino function.

\section{Scheme 1}

The results obtained demonstrated that this approach is versatile and can be conveniently used for the preparation of different building blocks bearing only a free hydroxyl group at C-6 with presenting different functional groups at anomeric position, including the thio-cyanomethyl group currently employed for protein glycosylation. These intermediates can be conveniently glycosylated with different sugar donors, allowing the preparation of glycans used for the synthesis of glycoconjugated derivatives (neo-glycoproteins and glycosphingolipids) including sialylated products such as the STn antigen.

\section{Results and Discussion}

\section{Enzymatic hydrolysis of different substrates}

In this work, two immobilized enzymes have been compared (CRL and AXE) for the preparation of various glucosamine and galactosamine building blocks. A screening has been performed at low substrate concentration $(10 \mathrm{mM})$ and in presence of $20 \%$ of acetonitrile in order to ensure the complete solubility and hydrolysis of the substrates (Table 1). 
The esterase AXE was used immobilized by covalent attachment on epoxy carrier since covalent immobilization generally ensures the stabilization of enzymes such as esterases or proteases.

Table 1. Enzymatic Hydrolysis of Different Derivatives of Glucosamine and Galactosamine

\begin{tabular}{cccc}
\hline Substrates & Products & CRL: yield (h) & AXE: yield (h) \\
\hline 1: $\mathrm{R}, \mathrm{R}_{4}=\mathrm{OAc} ; \mathrm{R}_{1}, \mathrm{R}_{3}=\mathrm{H} ; \mathrm{R}_{2}=\mathrm{NHAc}$ & $\mathbf{1 2}$ & $94 \%(24)$ & $10 \%(3)^{\mathrm{a}}$ \\
$\mathbf{1}^{\mathrm{b}}: \mathrm{R}, \mathrm{R}_{4}=\mathrm{OAc} ; \mathrm{R}_{1}, \mathrm{R}_{3}=\mathrm{H} ; \mathrm{R}_{2}=\mathrm{NHAc}$ & $\mathbf{1 2}$ & $80 \%(24)$ & - \\
2: $\mathrm{R}, \mathrm{R}_{3}=\mathrm{H} ; \mathrm{R}_{1}=\mathrm{OMe} ; \mathrm{R}_{2}=\mathrm{NHAc} \mathrm{R}_{4}=\mathrm{OAc}$ & $\mathbf{1 3}$ & $70 \%(24)$ & $94 \%(24)$ \\
3: $\mathrm{R}, \mathrm{R}_{3}=\mathrm{H} ; \mathrm{R}_{1}=\mathrm{SCH} \mathrm{CN}_{2} ; \mathrm{R}_{2}=\mathrm{NHAc} ; \mathrm{R}_{4}=\mathrm{OAc}$ & $\mathbf{1 4}$ & $68 \%(48)$ & $90 \%(24)$ \\
4: $\mathrm{R}, \mathrm{R}_{3}=\mathrm{H} ; \mathrm{R}_{1}=\mathrm{SEt} ; \mathrm{R}_{2}=\mathrm{NHAc} ; \mathrm{R}_{4}=\mathrm{OAc}$ & $\mathbf{1 5}$ & $<10 \%(48)^{\mathrm{a}}$ & $85 \%(12)$ \\
5: $\mathrm{R}, \mathrm{R}_{3}=\mathrm{H} ; \mathrm{R}_{1}=\mathrm{SPh} ; \mathrm{R}_{2}=\mathrm{NHAc} ; \mathrm{R}_{4}=\mathrm{OAc}$ & $\mathbf{1 6}$ & $<10 \%(48)^{\mathrm{a}}$ & $65 \%(6)$ \\
\hline $\mathbf{6 :} \mathrm{R}, \mathrm{R}_{4}=\mathrm{OAc} ; \mathrm{R}_{1}, \mathrm{R}_{3}=\mathrm{H} ; \mathrm{R}_{2}=\mathrm{NPhth}$ & $\mathbf{1 7}$ & $76 \%(6)$ & $<10 \%(24)^{\mathrm{a}}$ \\
7: $\mathrm{R}, \mathrm{R}_{3}=\mathrm{H} ; \mathrm{R}_{1}=\mathrm{OMe} ; \mathrm{R}_{2}=\mathrm{NPhth} ; \mathrm{R}_{4}=\mathrm{OAc}$ & $\mathbf{1 8}$ & $85 \%(4)$ & $12 \%(8)^{\mathrm{a}}$ \\
8: $\mathrm{R}, \mathrm{R}_{3}=\mathrm{H} ; \mathrm{R}_{1}=\mathrm{SEt} ; \mathrm{R}_{2}=\mathrm{NPhth} ; \mathrm{R}_{4}=\mathrm{OAc}$ & $\mathbf{1 9}$ & $64 \%(24)$ & $30 \%(96)^{\mathrm{a}}$ \\
9: $\mathrm{R}, \mathrm{R}_{3}=\mathrm{H} ; \mathrm{R}_{1}=\mathrm{SPh} ; \mathrm{R}_{2}=\mathrm{NPhth} ; \mathrm{R}_{4}=\mathrm{OAc}$ & $\mathbf{2 0}$ & $38 \%(24)$ & $<10 \%(194)^{\mathrm{a}}$ \\
\hline $\mathbf{1 0} \mathbf{b}^{\mathrm{b}}: \mathrm{R}, \mathrm{R}_{3}=\mathrm{OAc} ; \mathrm{R}_{1}, \mathrm{R}_{4}=\mathrm{H} ; \mathrm{R}_{2}=\mathrm{NHAc}$ & $\mathbf{2 1}$ & $70 \%(30)$ & - \\
11: $\mathrm{R}, \mathrm{R}_{4}=\mathrm{H} ; \mathrm{R}_{1}=\mathrm{SEt} ; \mathrm{R}_{2}=\mathrm{NPhth} ; \mathrm{R}_{3}=\mathrm{OAc}$ & $\mathbf{2 2}$ & $80 \%(5)$ & - \\
\hline
\end{tabular}

${ }^{a}$ Yield evaluated by HPLC analysis without isolation of the product. ${ }^{b} \alpha / \beta=5 / 1$. Experimental conditions: substrate $10 \mathrm{mM}$, volume $15 \mathrm{~mL}$, phosphate buffer $50 \mathrm{mM}$, acetonitrile $20 \%$ (for substrates 6 and 7, $25 \%$ of acetonitrile was used), pH 5, r.t., enzyme $1 \mathrm{~g}$ of CRL-OD (1200 UI/g) or AXE (90 UI/g).

In the case of CRL, this enzyme was used immobilized by adsorption on hydrophobic carrier because this method is appropriate to obtain good stability and activity of lipases. ${ }^{[22]}$

Except for 2-deoxy-2-acetamido-1,3,4,6-tetra- $O$-acetyl- $\alpha$-D-glucopyranoside $\mathbf{1}$ (since AXE was reported to catalyze hydrolysis the anomeric position of pyranoses with acetoxy group), ${ }^{[27]}$ considering the other $N$-acetylated substrates $\mathbf{2 - 5}$, the esterase AXE allowed best performances. In fact, the pure $\alpha$ anomer of 1, with the anomeric acetyl leaving group, can be used as substrate for immobilized CRL according to the procedure previously reported. ${ }^{[28,29]}$ In this work, we used CRL immobilized on 
Sepabeads-OD (a C18 hydrophobic carrier) and the obtained results (Table 1) were similar (94\% of 2deoxy-2-acetamido-1,3,4-tri- $O$-acetyl- $\alpha$-D-glucopyranose 12) to those previously reported using $\mathrm{CRL}$ immobilized on octyl-agarose (a C8 hydrophobic carrier). However, CRL-Sepabeads-OD permitted much higher reaction rate providing almost quantitative hydrolysis of $\mathbf{1}$ in 24 hours. When the same reaction condition was used, the CRL immobilized on C8 agarose provided only $75 \%$ of the substrate hydrolyzed in 48 hours. The enzymatic hydrolysis of 1 was performed up to $20 \mathrm{mM}$ concentration (about $8 \mathrm{~g} / \mathrm{L}$ ) and $92 \%$ yield of $\mathbf{1 2}$ was obtained after 24 hours. In addition, the hydrolysis of $\mathbf{1}$ with CRL was also tested using the $\alpha$ and $\beta$ mixture (5/1) avoiding the separation of the two anomers after the chemical synthesis of this substrate (Table 1). The enzyme can be completely selective to provide the pure $\alpha$ anomer of $\mathbf{1 2}$ in $80 \%$ yield, corresponding to almost complete hydrolysis of the $\alpha$-form of $\mathbf{1}$. In this case, the $\beta$ anomer remains completely unreacted and can be easily separated from the $\alpha-\mathbf{1 2}$.

Using AXE, methyl 2-deoxy-2-acetamido-3,4-di- $O$-acetyl- $\beta$-D-glucopyranoside 13 was prepared in 94\% yield (Table 1), much better compared with the result obtained by means of CRL (70\% yield). Similarly, yields ranging from $65 \%$ to $90 \%$ of various sugar building blocks have been obtained with AXE, starting from $N$-acetyl glucosamine derivatives with an anomeric $S$-alkyl group, including the thio-cyanomethyl reactive linker used for the glycosylation of proteins. In fact, cyanomethyl 2-deoxy-2acetamido-3,4,-di- $O$-acetyl-1-thio- $\beta$-D-glucopyranoside 14 was prepared in $90 \%$ yield. This reaction was scaled up to $50 \mathrm{mM}$ concentration (about $20 \mathrm{~g} / \mathrm{L}$ ) of substrate 3 (see Table S1 in Supporting Information).

Similar results have been obtained in the hydrolysis of ethyl 2-deoxy-2-acetamido-3,4,6-tri-O-acetyl-1thio- $\beta$-D-glucopyranoside 4 providing ethyl 2-deoxy-2-acetamido-3,4-di- $O$-acetyl-1-thio- $\beta$-Dglucopyranoside 15 (85\% yields). Lower yield (Table 1) was obtained in the hydrolysis of phenyl 2deoxy-2-acetamido-3,4,6-tri- $O$-acetyl-1-thio- $\beta$-D-glucopyranoside 5 (65\% yield of product $\mathbf{1 6}$ ).

Also in the hydrolysis of the 2-deoxy-2-phthalimido glucopyranoside derivatives 6-9, good or very good yields were obtained, but in these cases CRL provided the best results. Starting from the 2-deoxy- 
2-phthalimido-1,3,4,6-tetra- $O$-acetyl- $\alpha$-D-glucopyranose 6, 76\% yield of 2-deoxy-2-phthalimido-1,3,4tri- $O$-acetyl- $\alpha$-D-glucopyranose 17 (with the anomeric $\alpha$-O-acetyl group) was obtained in $6 \mathrm{~h}$ of reaction (Table 1). As observed for other substrates, also in this case the reaction catalyzed by the Octyl-agarose derivative of CRL proceeded much slower (18 hours for complete hydrolysis of 6) compared with the CRL-OD derivative. This reaction was performed by increasing the substrate concentration up to $10 \mathrm{~g} / \mathrm{L}$ (see Table S2 Supporting Information).

Products with one free hydroxyl group at C-6 in good yields have also been obtained in the hydrolysis of methyl 2-deoxy-2-phthalimido-3,4,6-tri- $O$-acetyl- $\beta$-D-glucopyranoside 7, (85\% of product 18), and ethyl 2-deoxy-2-phthalimido-3,4,6-tri- $O$-acetyl-1-thio- $\beta$-D-glucopyranoside 8, (64\% of product 19). About $90 \%$ of these two substrates, characterized by a little O- or S-alkyl anomeric group, were hydrolyzed in 4 and 24 hours, respectively. Lower yield was obtained in the hydrolysis of phenyl 2deoxy-2-phthalimido-3,4,6-tri- $O$-acetyl-1-thio- $\beta$-D-glucopyranoside 9, because this reaction proceeded slowly (38\% yield of product $\mathbf{2 0}$ in 24 hours).

Finally, the enzymatic hydrolysis of galactosamine derivatives was also investigated. The hydrolysis of 2-deoxy-2-acetamido-1,3,4,6-tetra- $O$-acetyl- $\alpha$-D-galactopyranose 10 (Table 1 ), obtained by chemical synthesis in $\alpha$ and $\beta$ mixture (5/1), has been performed using CRL. This reaction provided 2-deoxy-2acetamido-1,3,4-tri- $O$-acetyl- $\alpha$-D-galactopyranose 21 (with the anomeric $O$-acetyl group) with 70\% yield in pure $\alpha$ form (the $\beta$ anomer is not hydrolyzed by CRL) and was scaled up by improving the substrate concentration up to $10 \mathrm{~g} / \mathrm{L}$ (70\% yield after purification). The hydrolysis of the ethyl 2-deoxy2-phthalimido-3,4,6-tri- $O$-acetyl-1-thio- $\beta$-D-galactopyranoside 11 proceeded much faster compared with the fully acetylated galactosamine 10, and ethyl 2-deoxy-2-phthalimido-3,4-di- $O$-acetyl-1-thio- $\beta$ D-galactopyranoside 22 was obtained in very good yield (80\% after purification) after only 5 hours of reaction (Table 1).

\section{Synthesis of disaccharides and glycoconjugated derivatives}


The different building blocks prepared by enzymatic hydrolysis have been then used as intermediates for the preparation of disaccharides. Starting from 14, products 23 and 24 (with the anomeric thiocyanomethyl reactive linker) have been synthesized in almost pure anomeric form with good yields (Scheme 2).

\section{Scheme 2}

These compounds, after activation to obtain the corresponding deprotected iminomethoxyethyl thioglycosides, (see Supporting Information), have been used for the preparation of neo-glycoproteins 23a and 24a in $80 \%$ and $100 \%$ yields respectively, as resulting by MS analysis (Figure 1) considering the $\%$ of glycosylated protein (RNase-A selected as model of carrier protein). These results demonstrate that the proposed approach, mediated by regioselective hydrolysis catalyzed by AXE, is suitable for the preparation of neo-glycoproteins with glycans having a glucosamine core.

\section{Figure 1}

However, when the building block 14 was used for the preparation of sialylated glyco-derivatives (potentially advantageous for the preparation of sialylated neo-glycoprotein), the glycosylation with sialyl xanthate afforded product 25 (55\% yield) in $3 / 2 \alpha / \beta$ mixture (Scheme 2$)$. Similarly, sialylation of $\mathrm{N}$-acetyl glucosamine and galactosamine building blocks $\mathbf{1 2}$ and 21, allowed preparation of the disaccharides $\mathbf{2 6}$ and $\mathbf{2 7}$ as a mixture of $\alpha / \beta$ anomers.

The difficulties intrinsic in the stereo-controlled synthesis of $\alpha$-sialosides have been largely reported and complex procedures are required in order to obtain pure or almost pure anomers. ${ }^{[30]}$ In fact, $\alpha / \beta$ mixtures are obtained in different ratio using monodeprotected sugar acceptors, regardless the protection used for

the C-2 amino group of the pyranose acceptor or using precursors with the 2-azido group. ${ }^{[31,32]}$ In our 
work, this effect was observed regardless the kind of sialyl-donor used in the glycosylation of 2-deoxy2-acetamido glucose or galactose building blocks. In addition, the sialylation of $\mathbf{2 1}$ was investigated in different conditions (including the use of sialyl chloride donor), but in all cases similar yields and an anomeric mixtures of $\mathbf{2 7}$ was obtained (see Supporting Information).

Surprisingly, high stereoselectivity was obtained when $\mathrm{N}$-phthalimido glucosamine or galactosamine intermediates were considered for the sialylation after enzymatic deprotection at C-6. Accordingly, it was possible to perform the preparation of sialyl-disaccharides with different reactive groups at C-1, in pure or almost pure $\alpha$-form (Scheme 3). Product 28 (with 1- $\alpha$-acetoxy) was obtained in $70 \%$ yield as almost pure $\alpha$ anomer, allowing results much better compared with those previously reported. ${ }^{[31]}$ Similarly, pure $\alpha$ anomer of $\mathbf{2 9}$ (with $1-\beta$-methoxy) was obtained in $64 \%$ yield.

\section{Scheme 3}

Much poorer performances were observed when sialyl xanthate was used as donor for sialylation of $N$ phthalimido- glucosamine 19 and galactosamine 22 (with 1- $\beta$-thioethyl), probably as consequence of the activation of the anomeric S-alkyl group in the reaction condition used that causes the formation of by-products. In fact, starting from $N$-phthalyl-glucosamine 19, pure 30 was obtained only in $32 \%$ yield, and the sialyl-Tn derivative $\mathbf{3 1}$ was produced in 30\% yield from $\mathrm{N}$-phthalyl-galactosamine $\mathbf{2 2}$ (see Supporting Information). For improving the yield in the sialylation of $N$-phthalimido building blocks, the sialyl chloride was investigated as donor in the glycosylation of intermediates 19 and 22 (Scheme 3). In this condition, $65 \%$ and $70 \%$ yields were obtained respectively for product $\mathbf{3 0}$ and sialyl-Tn precursor 31 (in both cases as 95/5 mixture of $\alpha / \beta$ isomers).

These results suggest that the presence of an acetamido group at position C-2, unlike the 2-phthalimido group, could be responsible for the formation of the $\beta$-anomer during sialylation. In particular, the 2acetamido group could be involved in the formation of a hydrogen bond with the carboxy-ester of the 
sialic acid donor. Accordingly, this effect was not observed in the glycosylation of $\mathrm{N}$-acetamidoglucosamine intermediate $\mathbf{1 4}$ with the Gal-TCA or Man-TCA. In fact, disaccharides 23 and 24 were obtained in pure $\beta$ and $\alpha$-form, respectively (Scheme 2). Consequently, the use of 2-phthalimido pyranoses should be preferred for the synthesis of sialyl derivatives.

Finally, starting from the sialylated disaccharide 28 (Scheme 3), after removing the anomeric acetyl group (yielding $75 \%$ of the crude product $\mathbf{3 2}$ ) and activation as trichloroacetimidate (yield in $60 \%$ of $\mathbf{3 3}$ after purification), the glycosylation of the 3-O-benzoyl-azidosphingosine building block provided the sialylated glycosphingolipid $\mathbf{3 4}$ in $61 \%$ yield.

\section{Conclusions}

In summary, a new chemoenzymatic synthetic strategy has been investigated and optimized for the preparation of neo-glycoproteins and glycolipids with a core of glucosamine or galactosamine, which are interesting as potential anticancer agents. A regioselective enzymatic hydrolysis can be conveniently used for the synthesis of 2-amino-pyranose building blocks bearing free hydroxyl group in primary position, starting from different acetylated 2-deoxy-2-acetamido or 2-deoxy-2-phthalimido gluco- and galactopyranoses. However, depending on the product desired, the appropriate starting material (substrate) and enzyme should be selected.

Thus, AXE can be used for the synthesis of neo-glycoproteins with an $N$-acetyl glucosamine core. In fact, the hydrolysis catalyzed by this enzyme provided different intermediates with a $\beta$-1-thio-(S-alkyl) group in very good yields (from 65\% to 95\%). For example, cyanomethyl 2-deoxy-2-acetamido-3,4,-di$O$-acetyl-1-thio- $\beta$-D-glucopyranoside 14 was prepared in $90 \%$ yield and, after glycosylation, two disaccharides with the thiocyanomethyl reactive linker at anomeric position were obtained and used for the preparation of neo-glycoproteins.

CRL provides C-6 monodeprotected 2- $N$-phthalyl pyranose building blocks in good yields (from $65 \%$ to $85 \%$ ) with different groups at anomeric position that can be used for the preparation of new sialylated 
glycoderivatives. Accordingly, the synthesis of protected Sialyl-Tn antigen $\mathbf{3 1}$ has been performed in two steps (56\% yield) while the glycosphingolipid $\mathbf{3 4}$ has been prepared in 3 steps in $40 \%$ yield.

The monodeprotected compounds obtained in this work can be used as intermediates for the preparation of different products as potential new anticancer agents. Different glycosphingolipids will be prepared using this synthetic route and investigated as anticancer GM3 analogues.

\section{Experimental Section}

\section{Materials and general experimental methods}

2-acetamido-1,3,4,6-tetra- $O$-acetyl-2-deoxy- $\alpha$-D-glucopyranoside (1) and 2-acetamido-2-deoxy-Dgalactopyranoside, Candida rugosa lipase were purchased from Sigma-Aldrich (Italy, Milan). The octadecyl-Sepabeads $^{\mathrm{TM}}$ was kindly supplied by Resindion (Italy). Immobilized AXE was kindly donated by ACS Dobfar (Italy). All chemicals were purchased as reagent grade and used without further purification. All chemical reactions were carried out under $\mathrm{N}_{2}$ atmosphere and anhydrous conditions with freshly distilled solvents, unless otherwise noted. Reactions were monitored by thin-layer chromatography (TLC) on a pre-coated plate of silica gel 60 F254 (Merck) and detection by staining with sulfuric acid. Solvents were evaporated under reduced pressure and below $40{ }^{\circ} \mathrm{C}$ (water bath). Column chromatography was performed on silica gel 60 (230-400 mesh, Merck). ${ }^{1} \mathrm{H}$ NMR and ${ }^{13} \mathrm{C}$ NMR spectra were recorded at $400 \mathrm{MHz}$ with Bruker AVANCE DRX 400 spectrometer. The chemical shifts were referenced to the solvent peak, $7.26 \mathrm{ppm}\left({ }^{1} \mathrm{H}\right)$ and $77.16 \mathrm{ppm}\left({ }^{13} \mathrm{C}\right)$ for $\mathrm{CDCl}_{3}$ at $25{ }^{\circ} \mathrm{C}$, and coupling constants were given in Hz. High-resolution mass spectra (HRMS) were recorded with a Bruker micro-TOF spectrometer in electrospray ionization (ESI) mode, using Tuning-Mix as reference. All the new compounds were fully characterized by ${ }^{1} \mathrm{H}$ and ${ }^{13} \mathrm{C}$ NMR, as well as HRMS. All the known products were characterized only by ${ }^{1} \mathrm{H}$ NMR by comparison with literatures.

\section{Synthesis of substrates 1-11}


Synthesis of substrates 1-11 has been performed using conventional chemical procedures. Experimental detail and analytical characterization are reported in the Supporting Information.

\section{Immobilization of Candida rugosa lipase (CRL)}

Immobilization of CRL was performed slightly modifying the procedure previously reported. ${ }^{[33]}$ Briefly, the crude extract of CRL ( $2 \mathrm{~g}$ ) was diluted in $25 \mathrm{mM}$ phosphate buffer $\mathrm{pH} 7$ (32 mL) and kept stirring for $30 \mathrm{~min} .5 \mathrm{~g}$ of octadecyl-Sepabeads ${ }^{\mathrm{TM}}$, previously washed with the same buffer, was added and the suspension was stirred at r.t. for $3 \mathrm{~h}$. The enzyme derivative (CRL-OD) was then filtered and washed with distilled water.

The activity of the enzyme was measured at $\mathrm{pH} 7.0$ and r.t. in the hydrolysis of tripropionin according to the literature. ${ }^{[34]}$

\section{Enzymatic hydrolysis}

The enzymatic hydrolysis of substrates 1-11 (10 mM) was carried out in $50 \mathrm{mM}$ phosphate buffer (15 $\mathrm{mL}$ ) containing $20 \%$ acetonitrile (for 6 and 7, 25\% of acetonitrile for complete solubility of the substrates) under mechanical stirring. The reaction started after the addition of $1 \mathrm{~g}$ of immobilized enzyme CRL-OD (1200 UI/g) or AXE (90 UI/g). During the reaction, the $\mathrm{pH}$ of the solution was maintained by automatic titration. The course of the hydrolysis reaction was monitored by HPLC (HPLC analysis: $30-50 \%$ acetonitrile in phosphate buffer $(10 \mathrm{mM})$ at $\mathrm{pH} 4$, flow rate $1.0 \mathrm{~mL} / \mathrm{min}, \lambda=$ $210 \mathrm{~nm}$ ) and TLC. After complete or almost-complete consumption of the substrate, the reaction was stopped by biocatalyst filtration, and the obtained products were isolated by extraction with ethyl acetate followed by purification by flash chromatography (product 12, 13 and 14: $\mathrm{CH}_{2} \mathrm{Cl}_{2}-\mathrm{MeOH}, 95: 5$, product 15: $\mathrm{CH}_{2} \mathrm{Cl}_{2}-\mathrm{Et}_{2} \mathrm{O}, 7: 3$, product 16: EtOAc-Hexane, 4:1, product 17: Toluene-EtOAc, 3:2, product 18 and 21: Hexane-EtOAc, 1:1, product 19, 20 and 22: Hexane-EtOAc, 3:2) and characterized by NMR spectra and mass spectrometry. 


\section{Analytical data of enzymatic products $12-22\left({ }^{1} \mathrm{H},{ }^{13} \mathrm{C}\right.$ NMR and MS)}

2-acetamido-1,3,4-tri-O-acetyl-2-deoxy- $\alpha$-D-glucopyranoside (12). $\mathrm{R}_{\mathrm{f}}=0.36\left(\mathrm{CH}_{2} \mathrm{Cl}_{2}-\mathrm{MeOH}, 95: 5\right)$. The ${ }^{1} \mathrm{H}$ NMR is accordance with the literature previously reported. ${ }^{[28]}{ }^{1} \mathrm{H}$ NMR $\left(400 \mathrm{MHz}, \mathrm{CDCl}_{3}\right): \delta$ $6.30(\mathrm{~d}, J=3.3 \mathrm{~Hz}, 1 \mathrm{H}, \mathrm{H}-1), 5.64$ (d, J=8.2 Hz, 1H, NH), 5.32 (t, J=9.8 Hz, 1H, H-3), 5.18 (t, J=9.6 Hz, 1H, H-4), 4.49 (m, 1H, H-2), 3.84 (m, 1H, H-5), 3.60, 3.74 (dd, 2H, H-6), 2.22 (s, 3H, OAc), 2.11 (s, 3H, OAc), 2.05 (s, 3H, OAc), 1.96 (s, 3H, NAc).

Methyl 2-acetamido-3,4-di-O-acetyl-2-deoxy- $\beta$-D-glucopyranoside (13). The ${ }^{1} \mathrm{H}$ NMR is in accordance with the literature previously reported. ${ }^{[35]} \mathrm{R}_{\mathrm{f}}=0.30\left(\mathrm{CH}_{2} \mathrm{Cl}_{2}-\mathrm{MeOH}, 95: 5\right) .{ }^{1} \mathrm{H} \mathrm{NMR}$ (400 MHz, $\left.\mathrm{CDCl}_{3}\right): \delta 5.90(\mathrm{~d}, J=8.4 \mathrm{~Hz}, 1 \mathrm{H}, \mathrm{NH}), 5.30(\mathrm{dd}, J=10.2,9.8 \mathrm{~Hz}, 1 \mathrm{H}, \mathrm{H}-3), 5.10(\mathrm{t}, J=9.8 \mathrm{~Hz}, 1 \mathrm{H}, \mathrm{H}-4)$, 4.60 (d, J=8.2 Hz, 1H, H-1), 4.22 (dd, J=12.6, 4.0 Hz, 1H, H-6a), 4.16 (dd, J=12.4, 2.4 Hz, 1H, H-6b), $3.82(\mathrm{dd}, J=10.3,8.4 \mathrm{~Hz}, 1 \mathrm{H}, \mathrm{H}-2), 3.70-3.78(\mathrm{~m}, 1 \mathrm{H}, \mathrm{H}-5), 3.50\left(\mathrm{~s}, 3 \mathrm{H}, \mathrm{OCH}_{3}\right), 2.08(\mathrm{~s}, 3 \mathrm{H}, \mathrm{OAc})$, 2.02 (s, 3H, OAc), 1.98 (s, 3H, NAc).

Cyanomethyl 2-acetamido-3,4-di-O-acetyl-2-deoxy-1-thio- $\beta$-D-glucopyranoside $\quad(\mathbf{1 4}) . \quad \mathrm{R}_{\mathrm{f}}=0.28$ $\left(\mathrm{CH}_{2} \mathrm{Cl}_{2}-\mathrm{MeOH}, 95: 5\right)$. The ${ }^{1} \mathrm{H}$ NMR is accordance with the literature previously reported. ${ }^{[36]}{ }^{1} \mathrm{H} \mathrm{NMR}$ $\left(400 \mathrm{MHz}, \mathrm{CDCl}_{3}\right): \delta 5.80(\mathrm{~d}, J=9.5 \mathrm{~Hz}, 1 \mathrm{H}, \mathrm{NH}), 5.20(\mathrm{t}, J=9.5 \mathrm{~Hz}, 1 \mathrm{H}, \mathrm{H}-3), 5.13$ (t, $J=9.5 \mathrm{~Hz}, 1 \mathrm{H}$, H-4), 4.74 (d, J=10.3 Hz, 1H, H-1), 4.20 (td, J=10.3, $9.5 \mathrm{~Hz}, 1 \mathrm{H}, \mathrm{H}-2), 3.74$ (d, J=17.3 Hz, 1H, $\mathrm{CH}_{2} \mathrm{CN}$ ), 3.80-3.71 (m, 1H, H-6a), 3.66-3.61 (m, 1H, H-5), 3.60-3.58 (m, 1H, H-6b), 3.32 (d, J=17.3 $\mathrm{Hz}, 1 \mathrm{H}, \mathrm{CH}_{2} \mathrm{CN}$ ), 2.07 (s, 3H, OAc), 2.06 (s, 3H, OAc), 1.97 (s, 3H, NAc).

Ethyl 2-acetamido-3,4-di-O-acetyl-2-deoxy-1-thio- $\beta$-D-glucopyranoside (15). The product is as a white solid, m.p.: $65-68{ }^{\circ} \mathrm{C} . \mathrm{R}_{\mathrm{f}}=0.36\left(\mathrm{CH}_{2} \mathrm{Cl}_{2}-\mathrm{Et}_{2} \mathrm{O}, 7: 3\right) .{ }^{1} \mathrm{H} \mathrm{NMR}\left(400 \mathrm{~Hz}, \mathrm{CDCl}_{3}\right): \delta 5.85(\mathrm{~d}, J=11.4 \mathrm{~Hz}$, 1H, NH), 5.20 (t, J=8.5 Hz, 1H, H-3), 5.03 (t, J=8.5 Hz, 1H, H-4), 4.61 (d, J=10.4 Hz, 1H, H-1), 4.10 (dd, J=19.3, 10.4 Hz, 1H, H-2), 3.76-3.52 (m, 3H, H-5, H-6), 2.76-273 (m, 2H, $\mathrm{SCH}_{2} \mathrm{CH}_{3}$ ), 2.04 (s, 3H, 
OAc), 2.03 (s, 3H, OAc), $1.95(\mathrm{~s}, 3 \mathrm{H}, \mathrm{NAc}), 1.25\left(\mathrm{t}, J=7.4 \mathrm{~Hz}, 3 \mathrm{H}, \mathrm{SCH}_{2} \mathrm{CH}_{3}\right) .{ }^{13} \mathrm{C} \mathrm{NMR}(100 \mathrm{~Hz}$ $\left.\mathrm{CDCl}_{3}\right): \delta 14.87\left(\mathrm{SCH}_{2} \mathrm{CH}_{3}\right), 20.78,20.84(\mathrm{OAc}), 23.38(\mathrm{NHAc}), 24.12\left(\mathrm{SCH}_{2} \mathrm{CH}_{3}\right), 53.33(\mathrm{C}-2), 61.74$ (C-6), 68.92 (C-4), 73.95 (C-3), 78.44 (C-5), 84.43 (C-1), 170.12, 170.29, 171.27 (C=O). ESI-HRMS (m/z) calcd for $\mathrm{C}_{14} \mathrm{H}_{23} \mathrm{NNaO}_{7} \mathrm{~S}[\mathrm{M}+\mathrm{Na}]^{+}: 372.1093$, found: 372.1078 .

Phenyl 2-acetamido-3,4-di-O-acetyl-2-deoxy-1-thio- $\beta$-D-glucopyranoside (16). The product is as a white solid, m.p.: 88-91 ${ }^{\circ} \mathrm{C} . \mathrm{R}_{\mathrm{f}}=0.30$ (EtOAc-Hexane, 4:1). ${ }^{1} \mathrm{H}$ NMR $\left(400 \mathrm{~Hz}, \mathrm{CDCl}_{3}\right): \delta 7.48-7.46(\mathrm{~m}$, 2H, ArH), 7.33-7.30 (m, 3H, ArH), 5.58 (d, J=9.4 Hz, 1H, NH), 5.24 (t, J=8.8 Hz, 1H, H-3), 5.01 (t, $J=9.8 \mathrm{~Hz}, 1 \mathrm{H}, \mathrm{H}-4), 4.88$ (d, J=10.2 Hz, 1H, H-1), 4.04 (dd, J=20.3, $10.4 \mathrm{~Hz}, 1 \mathrm{H}, \mathrm{H}-2), 3.74-3.69$ (m, 1H, H-5), 3.62-3.52 (m, 2H, H-6), 2.04 (s, 3H, OAc), 2.03 (s, 3H, OAc), 1.98 (s, 3H, NAc). ${ }^{13} \mathrm{C}$ NMR $\left(100 \mathrm{~Hz}, \mathrm{CDCl}_{3}\right): \delta$ 20.78, 20.84 (OAc), 23.49 (NHAc), 53.70 (C-2), 61.88 (C-6), 68.78, 73.76, 78.47 (C-3, C-4, C-5), 86.70 (C-1), 129.24, 132.50 (aromatic C), 170.06, 170.11, 171.23 (C=O). ESI-HRMS (m/z) calcd for $\mathrm{C}_{18} \mathrm{H}_{23} \mathrm{NNaO}_{7} \mathrm{~S}[\mathrm{M}+\mathrm{Na}]^{+}:$420.1093, found: 420.1069 .

1,3,4-tri-O-acetyl-2-phthalimido-2-deoxy- $\alpha$-D-glucopyranoside (17). $\mathrm{R}_{\mathrm{f}}=0.36$ (Toluene-EtOAc, 3:2). The ${ }^{1} \mathrm{H}$ NMR is accordance with the literature previously reported. ${ }^{[37]}{ }^{1} \mathrm{H}^{\mathrm{NMR}}\left(400 \mathrm{~Hz}, \mathrm{CDCl}_{3}\right): \delta$ 7.87-7.83 (m, 2H, phthalimido protons), 7.75-7.72 (m, 2H, phthalimido protons), 6.60 (dd, $J=11.5,9.1$ Hz, 1H, H-3), 6.29 (d, J=3.3 Hz, 1H, H-1), 5.15 (t, J=9.6 Hz, 1H, H-4), 4.71 (dd, J=11.6, $3.3 \mathrm{~Hz}, 1 \mathrm{H}$, H-2), 4.15-4.08 (m, 1H, H-5), 3.82-3.62 (2m, 2H, H-6), 2.09 (s, 3H, OAc), 2.08 (s, 3H, OAc), 1.88 (s, $3 \mathrm{H}, \mathrm{OAc})$.

Methyl 3,4-di-O-acetyl-2-phthalimido-2-deoxy- $\beta$-D-glucopyranoside (18). The product is as colourless oil. $\mathrm{R}_{\mathrm{f}}=0.40$ (Hexane-EtOAc, 1:1). ${ }^{1} \mathrm{H}$ NMR $\left(400 \mathrm{~Hz}, \mathrm{CDCl}_{3}\right): \delta 7.88-7.84$ (m, 2H, phthalimido protons $\mathrm{H}$ ), 7.75-7.73 (m, 2H, phthalimido protons), 5.83 (dd, J=9.8, $1.6 \mathrm{~Hz}, 1 \mathrm{H}, \mathrm{H}-3), 5.34$ (d, J=9.6 Hz, 1H, H-1), 5.12 (t, J=9.2 Hz, 1H, H-4), 4.28 (dd, J=8.8, $2.6 \mathrm{~Hz}, 1 \mathrm{H}, \mathrm{H}-2), 3.84-3.81$ (m, 1H, H-5), 
3.71-3.64 (m, 2H, H-6), 3.45 (s, 3H, $\mathrm{OCH}_{3}$ ), 2.07 (s, 3H, OAc), 1.87 (s, 3H, OAc). ${ }^{13} \mathrm{C} \mathrm{NMR} \mathrm{(100} \mathrm{Hz,}$ $\mathrm{CDCl}_{3}$ ): $\delta 20.67$ (OAc), 20.92 (OAc), 50.65 (C-2), 60.52 (OMe), 61.21 (C-6), 66.45 (C-4), 70.17 (C-3), 72.80 (C-5), 90.63 (C-1), 124.07, 134.99 (aromatic C), 167.60-171.29 (C=O). ESI-HRMS (m/z) calcd for $\mathrm{C}_{19} \mathrm{H}_{21} \mathrm{NNaO}_{9}[\mathrm{M}+\mathrm{Na}]^{+}$: 430.1114, found: 430.1126 .

Ethyl 3,4-di-O-acetyl-2-phthalimido-2-deoxy-1-thio- $\beta$-D-glucopyranoside (19). $\mathrm{R}_{\mathrm{f}}=0.41$ (HexaneEtOAc, 3:2). The ${ }^{1} \mathrm{H}$ NMR is accordance with the literature previously reported. ${ }^{[38]}{ }^{1} \mathrm{H}$ NMR (400 MHz, $\left.\mathrm{CDCl}_{3}\right): \delta$ 7.75-7.95 (m, 4H, phthalimido protons), 5.90 (t, J=8.8 Hz, 1H, H-3), 5.52 (d, J=10.5 Hz, 1H, H-1), 5.16 (t, J=8.6 Hz, 1H, H-4), 4.40 (t, J=9.5 Hz, 1H, H-2), 4.31 (dd, J=11.7, $5.1 \mathrm{~Hz}, 1 \mathrm{H}, \mathrm{H}-5), 3.72$ (m, 1H, H-6a), 3.68 (m, 1H, H-6b), 2.60-2.82 (m, 2H, $\mathrm{SCH}_{2} \mathrm{CH}_{3}$ ), 2.15 (s, 3H, OAc), 1.89 (s, 3H, OAc), $1.22\left(\mathrm{t}, J=7.4 \mathrm{~Hz}, 3 \mathrm{H}, \mathrm{SCH}_{2} \mathrm{CH}_{3}\right)$.

Phenyl 3,4-di-O-acetyl-2-phthalimido-2-deoxy-1-thio- $\beta$-D-glucopyranoside $(\mathbf{2 0}) . \mathrm{R}_{\mathrm{f}}=0.38$ (HexaneEtOAc, 3:2). The ${ }^{1} \mathrm{H}$ NMR is accordance with the literature previously reported. ${ }^{[38]}{ }^{1} \mathrm{H}$ NMR (400 MHz, $\left.\mathrm{CDCl}_{3}\right): \delta$ 7.94-7.75 (m, 4H, phthalimido protons), 7.48-7.26 (m, 5H, Ph), 5.85 (dd, J=9.5 Hz, 1H, H-3), 5.79 (d, J=10.6 Hz, 1H, H-1), 5.14 (t, J=9.6 Hz, 1H, H-4), 4.39 (t, J=10.6 Hz, 1H, H-2), 3.84-3.61 (m, 3H, H-5, H-6), 2.05 (s, 3H, OAc), 1.87 (s, 3H, OAc).

2-acetamido-1,3,4-tri-O-acetyl-2-deoxy- $\alpha$-D-galactopyranoside $(21) . \mathrm{R}_{\mathrm{f}}=0.30$ (EtOAc-Hexane, 1:1). The ${ }^{1} \mathrm{H}$ NMR is accordance with the literature previously reported. ${ }^{[28]}{ }^{1} \mathrm{H}$ NMR $(400 \mathrm{MHz}, \mathrm{CDCl} 3): \delta$ 6.25 (d, J=3.6 Hz, 1H, H-1), 5.58 (bd, 1H, NH), 5.45 (bdd, 1H, H-4), 5.30 (dd, J=8.7, $3.1 \mathrm{~Hz}, 1 \mathrm{H}, \mathrm{H}-3$ ), 4.80 (ddd, J=11.0, 9.8, 3.6 Hz, 1H, H-2), 4.08 (t, J=12.8 Hz, 1H, H-5), 3.50-3.64 (m, 2H, H-6), 2.23 (s, 3H, OAc), 2.18 (s, 3H, OAc), 2.08 (s, 3H, OAc), 1.96 (s, 3H, NAc). 
Ethyl 3,4-di-O-acetyl-2-phthalimido-2-deoxy-1-thio- $\beta$-D-galactopyranoside (22). The product is as a white solid, m.p.: $78-80{ }^{\circ} \mathrm{C} . \mathrm{R}_{\mathrm{f}}=0.35$ (Hexane-EtOAc, 3:2). ${ }^{1} \mathrm{H} \mathrm{NMR}\left(400 \mathrm{~Hz}, \mathrm{CDCl}_{3}\right): \delta 7.87-7.85(\mathrm{~m}$, 2H, phthalimido protons), 7.76-7.74 (m, 2H, phthalimido protons), 5.85 (dd, J=10.6, $3.2 \mathrm{~Hz}, 1 \mathrm{H}, \mathrm{H}-3$ ), 5.50 (d, J=3.0 Hz, 1H, H-4), 5.48 (d, J=10.4 Hz, 1H, H-1), 4.63 (t, J=10.5 Hz, 1H, H-2), 3.98-3.95 (m, $1 \mathrm{H}, \mathrm{H}-5), 3.78,3.55$ (2m, 2H, H-6), 2.75-2.67 (m, 2H, $\left.\mathrm{SCH}_{2} \mathrm{CH}_{3}\right), 2.22(\mathrm{~s}, 3 \mathrm{H}, \mathrm{OAc}), 1.86$ (s, 3H, OAc), 1.21 (t, J=7.2 Hz, 3H, $\left.\mathrm{SCH}_{2} \mathrm{CH}_{3}\right) .{ }^{13} \mathrm{C} \mathrm{NMR}\left(100 \mathrm{~Hz}, \mathrm{CDCl}_{3}\right): \delta 15.11\left(\mathrm{SCH}_{2} \mathrm{CH}_{3}\right), 20.67(\mathrm{OAc})$, 20.92 (OAc), $24.71\left(\mathrm{SCH}_{2} \mathrm{CH}_{3}\right), 50.65$ (C-2), 61.21 (C-6), 67.97 (C-4), 69.07 (C-3), 77.69 (C-5), 81.85 (C-1), 123.77, 123.86, 134.42, 134.47, 134.54 (aromatic C), 167.60, 168.11, 169.80, 171.29 (C=O). ESI-HRMS (m/z) calcd for $\mathrm{C}_{20} \mathrm{H}_{23} \mathrm{NNaO}_{8} \mathrm{~S}[\mathrm{M}+\mathrm{Na}]^{+}: 460.1042$, found: 460.1025 .

\section{Synthesis of disaccharides 23-31}

Cyanomethyl (2',3',4',6'-tetra-O-acetyl- $\beta$-D-galactopyranosyl)-(1-6)-2-acetamido 3,4-di-O-acetyl-2deoxy-1-thio- $\beta$-D-glucopyranoside (23). 2,3,4,6-Tetra- $O$-acetyl- $\alpha$-D-galactopyranose trichloroacetimidate $(0.137 \mathrm{~g}, 0.278 \mathrm{mmol})$ and compound $14(0.05 \mathrm{~g}, 0.139 \mathrm{mmol})$ were co-evaporated with toluene $(2 \times 10 \mathrm{~mL})$ and dried under reduced pressure. The mixture was then dissolved in dry $\mathrm{CH}_{2} \mathrm{Cl}_{2}(25 \mathrm{~mL})$ in presence of $4 \AA$ molecular sieves and cooled at $0{ }^{\circ} \mathrm{C}$. The $\mathrm{BF}_{3} \cdot \mathrm{Et}_{2} \mathrm{O}(0.034 \mathrm{~mL}$, $0.278 \mathrm{mmol}$ ) was added and the reaction allowed to warm to r.t. After $2.5 \mathrm{~h}$, the reaction mixture was quenched with $\mathrm{Et}_{3} \mathrm{~N}$, filtered and concentrated in vacuo. The residue was purified by flash column chromatography (EtOAc-Et $\left.{ }_{2} \mathrm{O}, 3: 2\right)$ to afford disaccharide 23 as a white solid $(0.065 \mathrm{~g}, 68 \%) . \mathrm{R}_{\mathrm{f}}=0.37$ (EtOAc-Et $\left.{ }_{2} \mathrm{O}, 3: 2\right)$.White solid: m.p.: $106-108{ }^{\circ} \mathrm{C} .{ }^{1} \mathrm{H}$ NMR $\left(400 \mathrm{MHz}, \mathrm{CDCl}_{3}\right): \delta 5.71(\mathrm{~d}, \mathrm{~J}=10.0 \mathrm{~Hz}$, 1H, NH), 5.21-5.10 (m, 2H, H-4', H-3), 5.01 (dd, J=10.5, $3.0 \mathrm{~Hz}, 1 \mathrm{H}, \mathrm{H}-2$ '), 4.94 (t, J=9.1 Hz, 1H, H3'), 4.64 (d, J=10.1 Hz, 1H, H-1), 4.56 (d, J=7.8 Hz, 1H, H-1'), 4.21-4.09 (m, 4H, H-2, H-4, H-6a, H6a'), 3.93-3.87 (m, 2H, H-6b, H-6b'), 3.79-3.73 (m, 2H, H-5, CHCN), 3.65-3.60 (m, 1H, H-5'), 3.27 (d, $J=17.3 \mathrm{~Hz}, 1 \mathrm{H}, \mathrm{CHCN}), 1.96-2.14(7 \mathrm{~s}, 21 \mathrm{H}, \mathrm{OAc}) .{ }^{13} \mathrm{C} \mathrm{NMR}\left(100 \mathrm{MHz}, \mathrm{CDCl}_{3}\right): \delta 14.55\left(\mathrm{SCH}_{2} \mathrm{CN}\right)$, 20.39-29.57 (7CH $), 52.70$ (C-2), 61.38 (C-6), 67.14 (C-6'), 68.50 (C-5'), 68.81 (C-4), 68.85 (C-2'), 
70.88, 70.89 (C-3', C-4'), 73.39 (C-3), 77.77 (C-5), 83.48 (C-1), 101.44 (C-1'), $116.86\left(\mathrm{SCH}_{2} \mathrm{CN}\right)$, 169.56-171.40 (7C=O). ESI-HRMS $(\mathrm{m} / \mathrm{z})$ calcd for $\mathrm{C}_{28} \mathrm{H}_{38} \mathrm{~N}_{2} \mathrm{NaO}_{16} \mathrm{~S}[\mathrm{M}+\mathrm{Na}]^{+}$: 713.1840 , found: 713.1859.

Cyanomethyl (2',3',4',6'-tetra-O-acetyl- $\alpha$-D-mannopyranosyl)-(1 $\rightarrow 6)$-2-acetamido 3,4-di-O-acetyl-2deoxy-1-thio- $\beta$-D-glucopyranoside (24). 2,3,4,6-tetra- $O$-acetyl- $\alpha$-D-mannopyranose trichloroacetimidate $(0.20 \mathrm{~g}, 0.417 \mathrm{mmol})$ and compound $14(0.075 \mathrm{~g}, 0.208 \mathrm{mmol})$ were co-evaporated with toluene $(2 \times 10$ $\mathrm{mL})$ and dried under reduced pressure. The mixture was then dissolved in dry $\mathrm{CH}_{2} \mathrm{Cl}_{2}(25 \mathrm{~mL})$ in presence of $4 \AA$ molecular sieves and cooled at $0{ }^{\circ} \mathrm{C}$. The $\mathrm{BF}_{3} \cdot \mathrm{Et}_{2} \mathrm{O}(0.058 \mathrm{~mL}, 0.417 \mathrm{mmol})$ was added and the reaction allowed to warm to r.t. After $2.5 \mathrm{~h}$, the reaction mixture was quenched with $\mathrm{Et}_{3} \mathrm{~N}$, filtered and concentrated in vacuum. The residue was purified by flash column chromatography

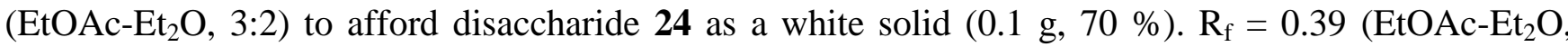
3:2). White solid: m.p.: 99-102 ${ }^{\circ} \mathrm{C} .{ }^{1} \mathrm{H}$ NMR (400 MHz, $\left.\mathrm{CDCl}_{3}\right): \delta 5.92$ (d, J=9.6 Hz, 1H, NH), 5.315.01 (m, 5H, H-4', H-3', H-1', H-4, H-4', H-5'), 4.66 (d, J=10.6 Hz, 1H, H-1), 4.58 (dd, J=13.6, 2.1 Hz, 1H, H-3), 4.28-4.03 (m, 5H, H-2, H-2', H-6, Ha-6'), 3.86 (t, J=9.6 Hz, 1H, H-5), 3.71-3.65 (m, 2H, CHCN, Hb-6'), 3.30 (d, J=17.6 Hz, 1H, CHCN), 2.14, 2.13, 2.11, 2.09, 2.04, 1.98, 1.96 (7s, 21H, OAc). ${ }^{13} \mathrm{C} \mathrm{NMR}\left(100 \mathrm{MHz}, \mathrm{CDCl}_{3}\right): \delta 14.72\left(\mathrm{SCH}_{2} \mathrm{CN}\right), 20.97-20.77\left(6 \mathrm{CH}_{3}, \mathrm{OAc}\right), 23.21\left(\mathrm{CH}_{3}, \mathrm{NAc}\right), 52.96$ (C-2), 62.33 (C-6, C'-6) , 62.62 (C'-2), 65.73, 68.67, 69.70, 70.13 (C-3, C'-3, C'-4, C'-5, C-4), 75.30 (C-5), 83.09 (C-1), 100.06 (C'-1), $116.17\left(\mathrm{SCH}_{2} \mathrm{CN}\right), 169.71-171.80(7 \mathrm{C}=\mathrm{O})$. ESI-HRMS (m/z) calcd for $\mathrm{C}_{28} \mathrm{H}_{38} \mathrm{~N}_{2} \mathrm{NaO}_{16} \mathrm{~S}[\mathrm{M}+\mathrm{Na}]^{+}:$713.1840, found: 713.1828 .

Cyanomethyl O-(methyl $\quad 5$-acetamido-4,7,8,9-tetra-O-acetyl-3,5-dideoxy-D-glycero- $\alpha / \beta$-D-galacto-2nonulopyranosylonate)-(2 $\rightarrow 6)$-2-acetamido-3,4-di-O-acetyl-2-deoxy- $\beta$-D-glucopyranose (25). The sialyl xanthates $(248 \mathrm{mg}, 0.42 \mathrm{mmol})$ and compound $14(100 \mathrm{mg}, 0.28 \mathrm{mmol})$ were dissolved in the $\mathrm{CH}_{3} \mathrm{CN}$ (4.5 mL) stirred for $1 \mathrm{~h}$ with $4 \AA$ powdered molecular sieves. Then it cooled to $-40{ }^{\circ} \mathrm{C}$, and NIS (187 mg, 
$0.83 \mathrm{mmol})$ and $\mathrm{TfOH}(36 \mu \mathrm{L}, 0.46 \mathrm{mmol})$ were added. After $2 \mathrm{~h}$, the reaction was quenched with $\mathrm{Et}_{3} \mathrm{~N}$. The mixture was diluted with $\mathrm{CH}_{2} \mathrm{Cl}_{2}$, filtered through celite, washed with $20 \%$ aqueous $\mathrm{Na}_{2} \mathrm{~S}_{2} \mathrm{O}_{3}$ solution, dried over $\mathrm{MgSO}_{4}$, and concentrated under reduced pressure. The residue was purified by column (Cy-EtOAc, 1:4) to obtain the disaccharide 25 (127 mg, 55\%) as $\alpha$ and $\beta$ isomer in the ratio of 3:2 from ${ }^{1} \mathrm{H}$ NMR. $\mathrm{R}_{\mathrm{f}}=0.35$ (Cy-EtOAc 1:4, twice). ${ }^{1} \mathrm{H}$ NMR (400 MHz, $\left.\mathrm{CDCl}_{3}\right): \delta 4.63,4.62, \mathrm{H}-1$ '; 3.81, 3.79, $\mathrm{COOCH}_{3} ; 3.51,3,25, \mathrm{SCH}_{2} \mathrm{CN} ; 2.64,2.48, \mathrm{H}-3 \mathrm{eq} ; 2.20-1.89$, OAc, NAc. ${ }^{13} \mathrm{C}$ NMR (100 $\left.\mathrm{MHz}, \mathrm{CDCl}_{3}\right): \delta$ 171.93-167.49, C=O; 115.18, CN; 98.42, 98.32, C-2; 83.53, 83.50, C-1'; 52.94, 52.77, $\mathrm{COOCH}_{3} ; 51.12$, C-2'; 49.33, C-5; 37.59, C-3; 23.22-20.61, NAc, OAc; 14.20, $\mathrm{SCH}_{2} \mathrm{CN}$. ESI-HRMS (m/z) calcd for $\mathrm{C}_{34} \mathrm{H}_{47} \mathrm{NO}_{22} \mathrm{Na}[\mathrm{M}+\mathrm{Na}]^{+}:$870.2579, found: 870.2571.

O-(methyl 5-acetamido-4,7,8,9-tetra-O-acetyl-3,5-dideoxy-D-glycero- $\alpha / \beta$-D-galacto-2nonulopyranosylonate)-(2-6)-2- acetamido-1,3,4-tri-O-acetyl-2-deoxy- $\alpha$-D-glucopyranose (26). The method in the literature ${ }^{[39]}$ was used with some modifications: A mixture of sialyl xanthates (137 mg, $0.23 \mathrm{mmol})$ and compound $12(40 \mathrm{mg}, 0.12 \mathrm{mmol})$ with $4 \AA$ powdered molecular sieves were dissolved in the dry $\mathrm{CH}_{3} \mathrm{CN}(2.4 \mathrm{~mL})$ and $\mathrm{CH}_{2} \mathrm{Cl}_{2}(1.2 \mathrm{~mL})$ stirring at r.t. for $1 \mathrm{~h}$. Further, AgOTf (50 mg, 0.19 mmol) and DTBP (46 $\mu \mathrm{L}, 0.21 \mathrm{mmol})$ were added, and the mixture was cooled to $-68{ }^{\circ} \mathrm{C}$ and kept protected from light. Then $\mathrm{PhSCl}(22 \mu \mathrm{L}, 0.19 \mathrm{mmol})$ in the dry $\mathrm{CH}_{2} \mathrm{Cl}_{2}(0.12 \mathrm{~mL})$ was added by running the solution down the cold wall of the reaction flask. Finally, the mixture was stirred for $2.5 \mathrm{~h}$ at $-68{ }^{\circ} \mathrm{C}$. After that, the mixture was diluted with a suspension of silica gel $(0.5 \mathrm{~g})$ in EtOAc $(3 \mathrm{~mL})$, filtered through celite, washed with saturated aqueous $\mathrm{NaHCO}_{3}$ and water, dried with $\mathrm{MgSO}_{4}$, and concentrated under reduced pressure. The residue was chromatographed (MeOH-EtOAc 1:20 to 1:5) to give disaccharide $26(58 \mathrm{mg}, 60 \%)$ as $\alpha$ and $\beta$ isomer in the ratio of $2: 1$ from ${ }^{1} \mathrm{H} \mathrm{NMR} . \mathrm{R}_{\mathrm{f}}=0.29$ (MeOH-EtOAc 1:10). ${ }^{1} \mathrm{H}$ NMR (400 MHz, $\left.\mathrm{CDCl}_{3}\right): \delta 6.22,6.16, \mathrm{H}-1$ '; 3.81, $3.79 \mathrm{COOCH}_{3} ; 2.63,2.47$, H-3eq; 2.20-2.05, OAc; 1.94-1.89 NAc. ${ }^{13} \mathrm{C}$ NMR (100 MHz, $\left.\mathrm{CDCl}_{3}\right): \delta$ 171.93-167.49, C=O; 98.42, 98.32, C-2; 90.82, 90.68, C-1'; 52.94, 52.77, $\mathrm{COOCH}_{3} ; 51.21,51.12$, C-2'; 49.33, C-5; 37.59, C-3; 
23.22-23.08, NAc; 21.18-20.61, OAc. ESI-HRMS (m/z) calcd for $\mathrm{C}_{34} \mathrm{H}_{47} \mathrm{NO}_{22} \mathrm{Na}[\mathrm{M}+\mathrm{Na}]^{+}:$857.2804, found: 857.2800 .

O-(Methyl 5-acetamido-4,7,8,9-tetra-O-acetyl-3,5-dideoxy-D-glycero- $\alpha / \beta$-D-galacto-2-

nonulopyranosylonate)-(2 $\rightarrow 6)-2$-acetamido-1,3,4-tri-O-acetyl-2-deoxy- $\alpha$-D-galactopyranose (27). A mixture of sialyl xanthates $(343 \mathrm{mg}, 0.58 \mathrm{mmol})$ and compound 21 (40 mg, $0.29 \mathrm{mmol})$ with $4 \AA$ powdered molecular sieves were dissolved in the dry $\mathrm{CH}_{3} \mathrm{CN}(6.0 \mathrm{~mL})$ and $\mathrm{CH}_{2} \mathrm{Cl}_{2}(3.0 \mathrm{~mL})$ stirring at r.t. for $1 \mathrm{~h}$. Further, AgOTf (123 mg, $0.47 \mathrm{mmol})$ and DTBP (115 $\mu \mathrm{L}, 0.53 \mathrm{mmol})$ were added, and the mixture was cooled to $-68{ }^{\circ} \mathrm{C}$ and kept protected from light. Then $\mathrm{PhSCl}(54 \mu \mathrm{L}, 0.47 \mathrm{mmol})$ in the dry $\mathrm{CH}_{2} \mathrm{Cl}_{2}(0.3 \mathrm{~mL})$ was added by running the solution down the cold wall of the reaction flask. Finally, the mixture was stirred for $3 \mathrm{~h}$ at $-68{ }^{\circ} \mathrm{C}$. After that, the mixture was diluted with a suspension of silica gel $(1.25 \mathrm{~g})$ in EtOAc $(7.5 \mathrm{~mL})$, filtered through celite, washed with saturated aqueous $\mathrm{NaHCO}_{3}$ and water, dried with $\mathrm{MgSO}_{4}$, and concentrated under reduced pressure. The residue was chromatographed (MeOH-EtOAc 0:1 to 1:9) to give disaccharide $27(150 \mathrm{mg}, 64 \%)$ as $\alpha$ and $\beta$ isomer in the ratio of $1: 1$ from ${ }^{1} \mathrm{H}$ NMR. $\mathrm{R}_{\mathrm{f}}=0.26$ (EtOAc, twice). ${ }^{1} \mathrm{H}$ NMR $\left(400 \mathrm{MHz}, \mathrm{CDCl}_{3}\right): \delta 6.18, \mathrm{H}-1$ '; $3.78,3.76$ $\mathrm{COOCH}_{3} ; 2.50,2.43, \mathrm{H}-3 \mathrm{eq} ; 2.18-1.85$, OAc, NAc. ${ }^{13} \mathrm{C} \mathrm{NMR}\left(100 \mathrm{MHz}, \mathrm{CDCl}_{3}\right): \delta$ 172.06-167.15, $\mathrm{C}=\mathrm{O} ; 98.84,98.58, \mathrm{C}-2 ; 90.32, \mathrm{C}-1$ '; 53.12, 52.03, $\mathrm{COOCH}_{3} ; 49.33$, C-2’; 48.00, C-5; 37.88, 36.57, C3; 23.26-20.81, NAc, OAc. ESI-HRMS (m/z) calcd for $\mathrm{C}_{34} \mathrm{H}_{47} \mathrm{NO}_{22} \mathrm{Na}[\mathrm{M}+\mathrm{Na}]^{+}:$857.2804, found: 857.2815 .

O-(methyl 5-acetamido-4,7,8,9-tetra-O-acetyl-3,5-dideoxy-D-glycero- $\alpha$-D-galacto-2-

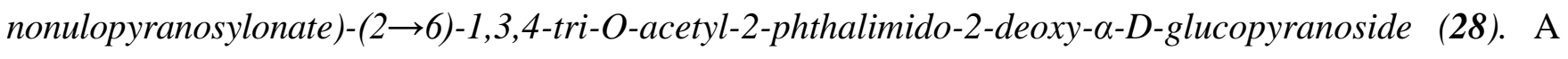
mixture of sialyl xanthates $(912 \mathrm{mg}, 1.54 \mathrm{mmol})$ and acceptor 17 (370 mg, $0.85 \mathrm{mmol})$ with $4 \AA$ powdered molecular sieves were dissolved in the dry $\mathrm{CH}_{3} \mathrm{CN}(17.2 \mathrm{~mL})$ and $\mathrm{CH}_{2} \mathrm{Cl}_{2}(8.6 \mathrm{~mL})$ stirring at r.t. for $1 \mathrm{~h}$. Further, AgOTf (360 mg, $1.38 \mathrm{mmol})$ and DTBP (337 $\mu \mathrm{L}, 1.55 \mathrm{mmol})$ were added, and the 
mixture was cooled to $-68{ }^{\circ} \mathrm{C}$ and kept protected from light. Then $\mathrm{PhSCl}(337 \mu \mathrm{L}, 1.38 \mathrm{mmol})$ in the dry $\mathrm{CH}_{2} \mathrm{Cl}_{2}(0.86 \mathrm{~mL})$ was added by running the solution down the cold wall of the reaction flask. Finally, the mixture was stirred for $3 \mathrm{~h}$ at $-68{ }^{\circ} \mathrm{C}$. After that, the mixture was diluted with a suspension of silica gel $(3.6 \mathrm{~g})$ in EtOAc $(22.5 \mathrm{~mL})$, filtered through celite, washed with saturated aqueous $\mathrm{NaHCO}_{3}$ and water, dried with $\mathrm{MgSO}_{4}$, and concentrated under reduced pressure. The residue was chromatographed (Cy-EtOAc 1:3) to give disaccharide $28(540 \mathrm{mg}, 70 \%) . \mathrm{R}_{\mathrm{f}}=0.31$ (Cy-EtOAc 1:3, twice). ${ }^{1} \mathrm{H}$ NMR (400 MHz, $\mathrm{CDCl}_{3}$ ): $\delta$ 7.84-7.81 (m, 2H, phthalimido protons), 7.73-7.71 (m, 2H, phthalimido protons), 6.52 (dd, J=9.2, $2.2 \mathrm{~Hz}, 1 \mathrm{H}, \mathrm{H}-3$ '), 6.24 (d, J=3.9 Hz, 1H, H-1'), 5.35-5.15 (m, 3H, H-4', H-7, H-8), 4.89-4.82 (m, 1H, H-4), 4.68 (dd, J=8.2, 3.6 Hz, 1H, H-2'), 4.28-4.23 (m, 2H, H-5', H-9a), 4.03-3.99 (m, 4H, Ha-6', H-5, H-6, H-9b), 3.80 (s, 3H, $\mathrm{COOCH}_{3}$ ), 3.40 (dd, J=11.4, 1.6 Hz, 1H, Hb-6'), 2.65 (dd, $J=12.7,4.4 \mathrm{~Hz}, 1 \mathrm{H}, \mathrm{H}-3 \mathrm{eq}), 2.14$ (s, 3H, OAc), 2.13 (s, 3H, OAc), 2.09 (s, 3H, OAc), 2.05 (s, 3H, OAc), 2.03 (s, 3H, OAc), 2.02 (s, 3H, OAc), 2.01 (s, 3H, OAc), 1.96 (t, J=3.6 Hz, 1H, H-3ax), 1.85 (s, $3 \mathrm{H}, \mathrm{NAc}) .{ }^{13} \mathrm{C}$ NMR $\left(100 \mathrm{MHz}, \mathrm{CDCl}_{3}\right): \delta 171.17,170.73,170.40,170.32,170.22,170.18,169.83$, 169.56, 169.52, $167.79(\mathrm{C}=\mathrm{O}), 134.51,123.81$ (aromatic C), 98.46 (C-2), 90.80 (C-1'), 72.47, 70.74, 69.26, 69.14, 68.01, 67.50, 67.33 (C-6, C-5', C-4', C-4, C-8, C-3', C-7), 62.60 (C-9), 62.30 (C-6'), 53.67 (C-2'), $53.05\left(\mathrm{COOCH}_{3}\right), 49.50$ (C-5), 37.89 (C-3), $23.33\left(\mathrm{CH}_{3}, \mathrm{NAc}\right), 21.29,21.15,20.99$, 20.96, 20.92, 20.85, $20.81\left(\mathrm{CH}_{3}, \mathrm{OAc}\right)$. ESI-HRMS (m/z) calcd for $\mathrm{C}_{34} \mathrm{H}_{47} \mathrm{NO}_{22} \mathrm{Na}[\mathrm{M}+\mathrm{Na}]^{+}: 931.2596$, found: 931.2590 .

Methyl O-(methyl-5-acetamido-4,7,8,9-tetra-O-acetyl-3,5-dideoxy-D-glycero- $\alpha$-D-galacto-2-

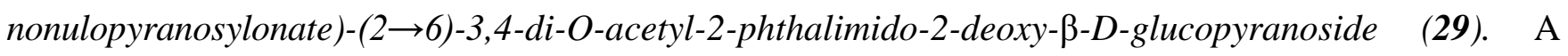
mixture of sialyl xanthates $(117 \mathrm{mg}, 0.20 \mathrm{mmol})$ and acceptor 18 (40 mg, $0.10 \mathrm{mmol})$ with $4 \AA$ powdered molecular sieves were dissolved in the dry $\mathrm{CH}_{3} \mathrm{CN}(1.66 \mathrm{~mL})$ and $\mathrm{CH}_{2} \mathrm{Cl}_{2}(0.83 \mathrm{~mL})$ stirring at r.t. for $1 \mathrm{~h}$. Further, AgOTf (50 mg, $0.20 \mathrm{mmol})$ and DTBP (45 $\mu \mathrm{L}, 0.20 \mathrm{mmol})$ were added, and the mixture was cooled to $-68{ }^{\circ} \mathrm{C}$ and kept protected from light. Then $\mathrm{PhSCl}(24 \mu \mathrm{L}, 0.21 \mathrm{mmol})$ in the dry 
$\mathrm{CH}_{2} \mathrm{Cl}_{2}(0.13 \mathrm{~mL})$ was added by running the solution down the cold wall of the reaction flask. Finally, the mixture was stirred for $3 \mathrm{~h}$ at $-68{ }^{\circ} \mathrm{C}$. After that, the mixture was diluted with a suspension of silica gel $(0.42 \mathrm{~g})$ in EtOAc $(2.5 \mathrm{~mL})$, filtered through celite, washed with saturated aqueous $\mathrm{NaHCO}_{3}$ and water, dried with $\mathrm{MgSO}_{4}$, and concentrated under reduced pressure. The residue was chromatographed (Cy-EtOAc 1:3) to give disaccharide 29 (55 mg, 64\%). $\mathrm{R}_{\mathrm{f}}=0.47$ (Cy-EtOAc 1:3, twice). ${ }^{1} \mathrm{H}$ NMR (400 $\left.\mathrm{MHz}, \mathrm{CDCl}_{3}\right): \delta$ 7.88-7.86 (m, 2H, phthalimido protons), 7.76-7.74 (m, 2H, phthalimido protons), 5.78 (dd, J=9.1, 1.2 Hz, 1H, H-3'), 5.44 (d, J=10.9 Hz, 1H, H-1'), 5.32-5.17 (m, 3H, H-4', H-7, H-8), 4.944.85 (m, 1H, H-4), 4.68 (dd, J=9.2, 3.6 Hz, 1H, H-2'), 4.28-4.23 (m, 2H, H-5', H-9a), 4.06-4.01 (m, 4H, Ha-6', H-5, H-6, H-9b), 3.80 (s, 3H, $\mathrm{COOCH}_{3}$ ), 3.40 (dd, J=11.4, $1.6 \mathrm{~Hz}, 1 \mathrm{H}, \mathrm{Hb}-6$ '), 3.31 (s, 3H, $\mathrm{OCH}_{3}$ ), 2.65 (dd, J=12.7, $\left.4.4 \mathrm{~Hz}, 1 \mathrm{H}, \mathrm{H}-3 \mathrm{eq}\right), 2.13$ (s, 3H, OAc), 2.09 (s, 3H, OAc), 2.05 (s, 3H, OAc), 2.03 (s, 3H, OAc), 2.02 (s, 3H, OAc), 2.01 (s, 3H, OAc), 1.96 (t, J=3.6 Hz, 1H, H-3ax), 1.86 (s, 3H, NAc). ${ }^{13} \mathrm{C}$ NMR $\left(100 \mathrm{MHz}, \mathrm{CDCl}_{3}\right): \delta 171.17,170.72,170.39,170.33,170.22,170.18,169.83,169.56$, 169.51, $167.80(\mathrm{C}=\mathrm{O}), 134.51,123.81$ (aromatic C), 98.46 (C-2), 91.90 (C-1'), 72.47, 70.74, 69.26, 69.14, 68.01, 67.50, 67.33 (C-6, C-5', C-4', C-4, C-8, C-3', C-7), 62.60 (C-9), 62.30 (C-6'), 60.53 $\left(\mathrm{OCH}_{3}\right), 53.67\left(\mathrm{COOCH}_{3}\right), 53.05\left(\mathrm{C}-2\right.$ ') $, 49.50(\mathrm{C}-5), 37.89(\mathrm{C}-3), 23.33\left(\mathrm{CH}_{3}, \mathrm{NAc}\right), 21.29,21.15$, 20.99, 20.96, 20.92, $20.85\left(\mathrm{CH}_{3}\right.$, OAc). ESI-HRMS (m/z) calcd for $\mathrm{C}_{34} \mathrm{H}_{47} \mathrm{NO}_{22} \mathrm{Na}[\mathrm{M}+\mathrm{Na}]^{+}$: 903.2647 , found: 903.2658 .

Ethyl O-(methyl-5-acetamido-4,7,8,9-tetra-O-acetyl-3,5-dideoxy-D-glycero- $\alpha$ - D-galacto-2-

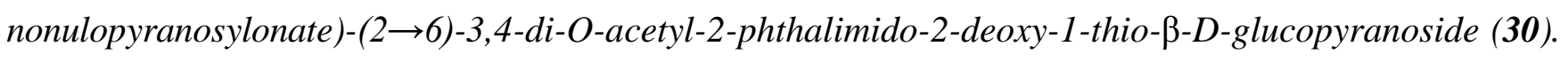
The method in the literature was used ${ }^{[40]}$ with some modifications: The acceptor 19 (20 mg, $\left.0.046 \mathrm{mmol}\right)$ and acetochloroneuraminate methyl ester $(70 \mathrm{mg}, 0.138 \mathrm{mmol})$ in the dry $\mathrm{CH}_{2} \mathrm{Cl}_{2}(4.6 \mathrm{ml})$ were stirred with $4 \AA$ powdered molecular sieves for $1 \mathrm{~h}$ at r.t.. Then it was cooled to $-45^{\circ} \mathrm{C}$ and kept protected from light, and AgOTf (83 mg, $0.322 \mathrm{mmol}$ ) was added. The mixture was gradually warmed to r.t. during 12 $\mathrm{h}$, and further stirred at r.t. for $3 \mathrm{~h}$. At last, filtered by celite and concentrated under reduced pressure. 
The residue was chromatographed (DCM-MeOH 9:1) to give disaccharide $\mathbf{3 0}(27 \mathrm{mg}, 65 \%)$. $\mathrm{R}_{\mathrm{f}}=0.41$ (Cy-EtOAc 1:3, twice). ${ }^{1} \mathrm{H}$ NMR (400 MHz, $\left.\mathrm{CDCl}_{3}\right): \delta$ 7.88-7.85 (m, 2H, phthalimido protons), 7.76$7.74\left(\mathrm{~m}, 2 \mathrm{H}\right.$, phthalimido protons), 5.81 (dd, J=9.1, $\left.1.2 \mathrm{~Hz}, 1 \mathrm{H}, \mathrm{H}-3^{\prime}\right), 5.45$ (d, J=10.9 Hz, 1H, H-1'), 5.30-5.17 (m, 3H, H-4', H-7, H-8), 4.94-4.85 (m, 1H, H-4), 4.51 (dd, J=9.2, 3.6 Hz, 1H, H-2'), 4.364.30 (m, 2H, H-5', H-9a), 4.17-4.02 (m, 5H, H-6', H-5, H-6, H-9b), 3.80 (s, 3H, COOCH 3 ), 2.73-2.55 (m, 3H, H-3eq, $\mathrm{SCH}_{2} \mathrm{CH}_{3}$ ), 2.13 (s, 3H, OAc), 2.09 (s, 3H, OAc), 2.05 (s, 3H, OAc), 2.03 (s, 3H, OAc), 2.02 (s, 3H, OAc), 2.01 (s, 3H, OAc), 1.96 (t, J=3.6 Hz, 1H, H-3ax), 1.85 (s, 3H, NAc), 1.23 (t, J=1.9 $\left.\mathrm{Hz}, 3 \mathrm{H}, \mathrm{SCH}_{2} \mathrm{CH}_{3}\right) .{ }^{13} \mathrm{C} \mathrm{NMR}\left(100 \mathrm{MHz}, \mathrm{CDCl}_{3}\right): \delta 172.06,172.00,170.99,170.56,170.36,170.33$, 170.09, 170.06, 169.61, $167.61(\mathrm{C}=\mathrm{O}), 134.66,123.08$ (aromatic C), 98.49 (C-2), 81.12 (C-1'), 76.19, 71.24, 70.15, 69.37, 68.96, 68.28, 67.34 (C-5’, C-6, C-4', C-4, C-8, C-3', C-7), 62.24 (C-9), 62.07 (C6'), $53.81\left(\mathrm{COOCH}_{3}\right), 51.89$ (C-2'), 49.14 (C-5), 37.88 (C-3), $23.97\left(\mathrm{SCH}_{2} \mathrm{CH}_{3}\right), 21.31\left(\mathrm{CH}_{3}, \mathrm{NAc}\right)$, 19.34, 19.31, 19.29, 19.25, $19.21\left(\mathrm{CH}_{3}, \mathrm{OAc}\right), 14.16\left(\mathrm{SCH}_{2} \mathrm{CH}_{3}\right)$. ESI-HRMS (m/z) calcd for $\mathrm{C}_{34} \mathrm{H}_{47} \mathrm{NO}_{22} \mathrm{Na}[\mathrm{M}+\mathrm{Na}]^{+}:$933.2575, found: 933.2585 .

Ethyl O-(methyl 5-acetamido-4,7,8,9-tetra-O-acetyl-3,5-dideoxy-D-glycero- $\alpha$ - D-galacto-2nonulopyranosylonate)-(2 $\rightarrow 6)-3,4$-di-O-acetyl-2-phthalimido-2-deoxy-1-thio- $\beta$-D-galactopyranoside (31). The acceptor $22(20 \mathrm{mg}, 0.046 \mathrm{mmol})$ and acetochloroneuraminate methyl ester $(70 \mathrm{mg}, 0.138$ mmol) in the dry $\mathrm{CH}_{2} \mathrm{Cl}_{2}(4.6 \mathrm{ml})$ were stirred with $4 \AA$ powdered molecular sieves for $1 \mathrm{~h}$ at r.t.. Then it was cooled to $-45^{\circ} \mathrm{C}$ and kept protected from light, and AgOTf ( $\left.83 \mathrm{mg}, 0.322 \mathrm{mmol}\right)$ was added. The mixture was gradually warmed to r.t. during $12 \mathrm{~h}$, and further stirred at r.t. for $3 \mathrm{~h}$. At last, filtered by celite and concentrated under reduced pressure. The residue was chromatographed (DCM-MeOH 9:1) to give disaccharide $31(29 \mathrm{mg}, 70 \%) . \mathrm{R}_{\mathrm{f}}=0.38$ (Cy-EtOAc 1:3, twice). ${ }^{1} \mathrm{H}$ NMR $\left(400 \mathrm{MHz}, \mathrm{CDCl}_{3}\right): \delta$ 7.87-7.85 (m, 2H, phthalimido protons), 7.76-7.73 (m, 2H, phthalimido protons), 5.87 (dd, J=9.4, 2.9 Hz, 1H, H-3'), 5.72-5.70 (m, 2H, NH, H-4'), 5.52 (d, J=10.9 Hz, 1H, H-1'), 5.37-5.35 (m, 1H, H-8), 5.27-5.20 (m, 1H, H-4), 5.14-5.10 (m, 1H, H-7), 4.72 (dd, J=12.2, $3.6 \mathrm{~Hz}, 1 \mathrm{H}, \mathrm{H}-6), 4.60$ (t, J=10.2 Hz, 
1H, H-2'), 4.19-4.05 (m, 3H, H-5, H-5', H-9a), 3.83 (s, 3H, $\mathrm{COOCH}_{3}$ ), 3.66-3.59 (m, 2H, Ha-6', H-9b), 3.44 (t, J=7.2 Hz, 1H, Hb-6'), 2.74-2.63 (m, 1H, $\mathrm{SCH}_{2} \mathrm{CH}_{3}$ ), 2.47 (dd, J=12.7, 4.4 Hz, 1H, H-3eq), 2.35 (s, 3H, OAc), 2.16 (s, 3H, OAc), 2.11 (s, 3H, OAc), 2.04 (s, 3H, OAc), 2.00 (s, 3H, OAc), 1.89 (s, 3H, OAc), 1.86 (s, 3H, NAc), 1.83 (t, J=10.4 Hz, 1H, H-3ax), 1.20 (t, J=9.6 Hz, 3H, $\left.\mathrm{SCH}_{2} \mathrm{CH}_{3}\right) .{ }^{13} \mathrm{C}$ NMR $\left(100 \mathrm{MHz}, \mathrm{CDCl}_{3}\right): \delta 172.13,170.71,170.67,170.65,170.43,170.17,169.56,168.06,167.61,167.06$ $(\mathrm{C}=\mathrm{O}), 134.57,134.40,131.76,131.39,123.83$ (aromatic C), 98.70 (C-2), 81.94 (C-1'), 75.10, 72.18, 72.08, 69.04, 69.01, 68.15, 67.70 (C-5', C-6, C-4, C-3', C-8, C-4', C-7), 62.50 (C-9), 60.55 (C-6'), $53.13\left(\mathrm{COOCH}_{3}\right), 50.76\left(\mathrm{C}-2^{\prime}\right), 48.32(\mathrm{C}-5), 37.06(\mathrm{C}-3), 24.66\left(\mathrm{SCH}_{2} \mathrm{CH}_{3}\right), 23.33\left(\mathrm{CH}_{3}, \mathrm{NAc}\right), 21.43$, 21.23, 21.07, 20.95, $20.65\left(\mathrm{CH}_{3}, \mathrm{OAc}\right), 15.03\left(\mathrm{CH}_{3}\right)$. ESI-HRMS (m/z) calcd for $\mathrm{C}_{34} \mathrm{H}_{47} \mathrm{NO}_{22} \mathrm{Na}$ $[\mathrm{M}+\mathrm{Na}]^{+}:$933.2575, found: 933.2580 .

\section{Synthesis and analysis of neo-glycoproteins}

Neo-glycoproteins $\mathbf{2 3 a}$ and $\mathbf{2 4 a}$, have been prepared according to the method previously reported ${ }^{[23]}$ by activation of the disaccharides $\mathbf{2 3}$ and $\mathbf{2 4}$ (Figure S1), followed by glycosylation of the protein RNase A.

\section{Synthesis of glycosphingolipid derivative 34}

(Methyl 5-acetamido-4,7,8,9-tetra-O-acetyl-3,5-dideoxy-D-glycero- $\alpha$-D-galacto-2-

nonulopyranosylonate)-(2 $\rightarrow 6)$-1,3,4-tri-O-acetyl-2-phthalimido-2-deoxy- $\beta$-D-glucopyranoside( $1 \rightarrow 1)$ (2S,3R,4E)-2-azido-3-O-benzoyl-4-octadecene-l,3-diol-(34). The $\mathrm{NH}_{2} \mathrm{CH}_{2} \mathrm{CH}_{2} \mathrm{NH}_{2}(18 \mathrm{uL})$ in the dry THF (5.2 mL) was added AcOH (18 uL) dropwise. Then compound 28 (200mg, $0.22 \mathrm{mmol})$ was added, and the mixture was further stirred at r.t. for $3 \mathrm{~h}$. The solvent was evaporated and the residue was taken into $\mathrm{CH}_{2} \mathrm{Cl}_{2}$ and washed progressively with $1.0 \mathrm{M} \mathrm{HCl}$, saturated aqueous $\mathrm{NaHCO}_{3}$ and water. The organic layer was dried over $\mathrm{MgSO}_{4}$ and concentrated to give the crude intermediate 32 with the yield of $75 \%$. Then the intermediate $32(110 \mathrm{mg}, 0.13 \mathrm{mmol})$ was dissolved in the dry $\mathrm{CH}_{2} \mathrm{Cl}_{2}(4.2 \mathrm{~mL})$, 
cooled to $-5{ }^{\circ} \mathrm{C}$, and trichloroacetonitrile $(420 \mu \mathrm{L})$ and $42 \mu \mathrm{L}$ of DBU were added at $-5{ }^{\circ} \mathrm{C}$, and the mixture was stirred at $-5{ }^{\circ} \mathrm{C}$ for $2 \mathrm{~h}$. After concentration, the residue was purified by flash column chromatography (Cy-EtOAc 1:4) to yield the trichloracetimidate 33 with $\alpha$ and $\beta(4: 1)$ mixture as pale yellow foam $(77 \mathrm{mg}, 60 \%) . \mathrm{R}_{\mathrm{f}}=0.45$ (EtOAc). The $33(60 \mathrm{mg}, 0.059 \mathrm{mmol})$ and 3-O-benzoylazidosphingosine (50 mg, $0.12 \mathrm{mmol}$ ) in $2.8 \mathrm{~mL}$ of dry $\mathrm{CH}_{2} \mathrm{Cl}_{2}$ were stirred with $4 \AA$ powdered molecular sieves $(500 \mathrm{mg})$ at r.t. for $1 \mathrm{~h}$. The mixture was then cooled to $-30{ }^{\circ} \mathrm{C}$, and $\mathrm{BF}_{3} \cdot \mathrm{Et}_{2} \mathrm{O}(60 \mu \mathrm{L}$, $0.48 \mathrm{mmol}$ ) was added dropwise, stirred for another $1.5 \mathrm{~h}$ at $-30{ }^{\circ} \mathrm{C}$, and then filtered through celite. Thefiltrate was washed with saturated aqueous $\mathrm{NaHCO}_{3}$ and water, dried over $\mathrm{MgSO}_{4}$ and concentrated under reduced pressure. The residue was applied to a flash chromatography eluted with Cy-EtOAc 1:5 to give $34(46 \mathrm{mg}, 61 \%)$ as an amorphous solid. $\mathrm{R}_{\mathrm{f}}=0.58$ (EtOAc). m.p.: $158-161{ }^{\circ} \mathrm{C} .{ }^{1} \mathrm{H}$ NMR (400 $\left.\mathrm{MHz}, \mathrm{CDCl}_{3}\right): \delta$ 7.98-7.95 (m, 2H, Ar-H), 7.86-7.82 (m, 2H, Ar-H), 7.73-7.71 (m, 2H, Ar-H), 7.57-7.53 (m, 1H, Ar-H), 7.44-7.40 (m, 2H, Ar-H), 5.83-5.64 (m, 1H, H-5'’), 5.58-5.46 (m, 2H, H-3', H-4'’), 5.41-5.30 (m, 6H, H-8, H-7, H-5', H-3', NH, H-2'), 4.87-4.84 (m, 1H, H-4), 4.34-4.28 (m, 2H, H-1', Ha-9), 4.12-4.01 (m, 6H, Hb-9, H-5, H-6, H-2', Ha-6', Ha-1 '’), 3.84-3.81 (m, 2H, Hb-1', Hb-6'), 3.79 (s, 3H, $\mathrm{COOCH}_{3}$ ), 3.58 (dd, J=5.7, $2.5 \mathrm{~Hz}, 1 \mathrm{H}, \mathrm{H}-4$ '), 2.57 (dd, J=12.8, 4.6 Hz, 1H, H-3eq), 2.14 (t, $J=1.5 \mathrm{~Hz}, 9 \mathrm{H}, 3 \mathrm{OAc}), 2.04$ (s, 6H, 2OAc), 2.03 (d, J=2.1 Hz, 2H, H2-6”), 2.02 (s, 3H, OAc), 1.93 (t, $J=5.9 \mathrm{~Hz}, 1 \mathrm{H}, \mathrm{H}-3 \mathrm{ax}), 1.87(\mathrm{~s}, 3 \mathrm{H}, \mathrm{NAc}), 1.24\left(\mathrm{~m}, 22 \mathrm{H}, 11 \times \mathrm{CH}_{2}\right), 0.87\left(\mathrm{t}, J=6.9 \mathrm{~Hz}, 3 \mathrm{H}, \mathrm{CH}_{3}\right) .{ }^{13} \mathrm{C}$ NMR (100 MHz, $\left.\mathrm{CDCl}_{3}\right): \delta 171.02(\mathrm{C}=\mathrm{O}), 170.67(\mathrm{C}=\mathrm{O}), 170.28(\mathrm{C}=\mathrm{O}), 170.24(\mathrm{C}=\mathrm{O}), 170.17$ $(2 \mathrm{C}=\mathrm{O}), 170.15(\mathrm{C}=\mathrm{O}), 170.03(\mathrm{C}=\mathrm{O}), 168.55(\mathrm{C}=\mathrm{O}), 167.70(\mathrm{C}=\mathrm{O}), 164.87(\mathrm{C}=\mathrm{O}), 138.92\left(\mathrm{C}-5^{\prime \prime}\right)$, 134.22 (C, $\mathrm{CH}$ aromatic), 133.13 (C, $\mathrm{CH}$ aromatic), 131.44 (C, $\mathrm{CH}$ aromatic), 129.70 (C, $\mathrm{CH}$ aromatic), 128.39 (C, CH aromatic), 123.60 (C-4’’), 98.76 (C-1'), 98.49 (C-2), 74.78, 72.61, 72.44, 70.96, 69.13, 69.03, 68.58, 68.12, 67.37 (C-3'”, C-3', C-4', C-6, C-4, C-5', C-1'”, C-8, C-7), 63.35 (C-2'’), 62.38 (C6’), 60.79 (C-9), 54.46 (C-2'), $52.65\left(\mathrm{COOCH}_{3}\right), 49.51$ (C-5), 38.19 (C-3), $31.91\left(\mathrm{CH}_{2}, \mathrm{C}-6\right.$ '’), 29.68, 29.66, 29.64, 29.57, 29.39, 29.34, 29.15, $28.62\left(\mathrm{CH}_{2}\right), 23.20\left(\mathrm{CH}_{3}, \mathrm{NAc}\right), 21.09\left(\mathrm{CH}_{3}, \mathrm{OAc}\right), 20.85$ 
$\left(\mathrm{CH}_{3}, \mathrm{OAc}\right), 20.84\left(\mathrm{CH}_{3}, \mathrm{OAc}\right), 20.82\left(\mathrm{CH}_{3}, \mathrm{OAc}\right), 20.76\left(\mathrm{CH}_{3}, \mathrm{OAc}\right), 20.70\left(\mathrm{CH}_{3}, \mathrm{OAc}\right), 14.10\left(\mathrm{CH}_{3}\right)$. ESI-HRMS (m/z) calcd for $\mathrm{C}_{57} \mathrm{H}_{82} \mathrm{~N}_{4} \mathrm{O}_{23} \mathrm{Na}[\mathrm{M}+\mathrm{Na}]^{+}$: 1300.5377 , found: 1300.5365 .

\section{Acknowledgments}

Authors would like specially to acknowledge Dr. Roberto Pavesi (ACS DOBFAR; Italy) that kindly provided immobilized AXE. Authors also thank the China Scholarship Council (CSC) for a Ph.D. fellowship to Changping Zheng. Financial supports from the Centre National de la Recherche Scientifique (CNRS) and the Sorbonne Université in France are gratefully acknowledged.

Keywords: enzymatic hydrolysis $\bullet$ sialyl-Tn antigen $\bullet$ glycosphingolipids $\bullet$ neo-glycoproteins

[1] Y. Zhang, D. Lu, M. Sollogoub, Y. Zhang, Carbohydr. Chem. 2016, 41, 238-254.

[2] R. D. Astronomo, D. R. Burton, Nat. Rev. Drug Discov. 2010, 9, 308-324.

[3] H. Qu, J. Liu, J. Wdzieczak-Bakala, D. Lu, X. He, W. Sun, M. Sollogoub, Y. Zhang, Eur. J. Med. Chem. 2014, 75, 247-25.

[4] G. Källenius, A. Pawlowski, B. Hamasur, S. B. Svenson, Trends Microbiol. 2008, 16, 456-462.

[5] G. J. L. Bernardes, B. Castagner, P. H. Seeberger, ACS Chem. Biol. 2009, 4, 703-713.

[6] P. Stallforth, B. Lepenies, A. Adibekian, P. H. Seeberger, J. Med. Chem. 2009, 52, 5561-5577.

[7] O. Finco, R. Rappuoli, Front. Immunol. 2014, 5, 1-6.

[8] T. M. Altamore, C. Fernandez-Garcia, A. H. Gordon, T. Hubscher, N. Promsawan, M. G. Ryadnov, A. J. Doig, D. N. Woolfson, T. Gallagher, Angew. Chem. Int. Ed. 2011, 50, 11167-11171.

[9] S. Hakomori, Y. Zhang, Chemistry \& Biology 1997, 4, 97-104.

[10] Y. Zhang, K. Iwabuchi, S. Nunomura, S. Hakomori, Biochemistry 2000, 39, 2459-2468.

[11] C. Zheng, M. Terreni, M. Sollogoub, Y. Zhang, Curr. Med. Chem. 2018, 25, 1-13 https://10.2174/0929867325666180129100619.

[12] Z. Yin, X. Huang, J. Carbohydr. Chem. 2012, 31, 143-186. 
[13] T. Bavaro, L. Piubelli, M. Amicosante, M. Terreni, Curr. Org. Chem. 2016, 20, 1150-1168.

[14] E. W. Adams, D. M. Ratner, P. H. Seeberger, N. Hacohen, Chembiochem. 2018, 9, 294-303.

[15] R. M. Wilson, S. J. Danishefsky, J. Am. Chem. Soc. 2013, 135, 14462-14472.

[16] L. Cipolla, F. Peri, C. Airoldi, Anticancer Agents Med. Chem. 2008, 8, 92-121.

[17] Y. S. Cho, Q. Wan, S. J. Danishefsky, Bioorg. Med. Chem. 2015, 13, 5259-5266.

[18] S. I. van Kasteren, S. J. Campbell, S. Serres, D. C. Anthony, N. R. Sibson, B. G. Davis, Proc, Natl. Acad. Sci. USA. 2009, 106, 18-23.

[19] D. P. Gamblin, E. M. Scanlan, B. G. Davis, Chem. Rev. 2009, 109, 131-163.

[20] D. Lu, Y. Hu, M. Sollogoub, Y. Zhang, Carbohydr. Res. 2014, 383, 89-96.

[21] X. Huang, L. Huang, H. Wang, X. S. Ye, Angew. Chem. Int. Ed. 2004, 43, 5221-5224.

[22] M. Filice, J. M. Guisan, M. Terreni, J. M. Palomo, Nat. Protoc. 2012, 7, 1783-1796.

[23] T. Bavaro, M. Filice, C. Temporini, S. Tengattini, I. Serra, C. F. Morelli, G. Massolini, M. Terreni, RSC Adv. 2014, 4, 56455-56465.

[24] C. Temporini, T. Bavaro, S. Tengattini, I. Serra, G. Marrubini, E. Calleri, F. Fasanella, L. Piubelli, F. Marinelli, L. Pollegioni, G. Speranza, G. Massolini, M. Terreni, J. Chrom. A 2014, 1367, 57-67. [25] C. Zheng, H. Qu, W. Liao, T. Bavaro, M. Terreni, M. Sollogoub, K. Ding, Y. Zhang, Eur. J. Med. Chem. 2018, 146, 613-620.

[26] T. Bavaro, M. Filice, P. Bonomi, Q. Abu Alassal, G. Speranza, J. M. Guisan, M. Terreni, Eur. J. Org. Chem. 2011, 6181-6185.

[27] A. Rise Moen, T. Anthonsen, Biocatal. Biotransform. 2009, 27, 226-236.

[28] M. Filice, T. Bavaro, R. Fernandez-Lafuente, M. Pregnolato, J. M. Guisan, J. M. Palomo, M. Terreni, Catal. Today 2009, 140, 11-18.

[29] M. Filice, J. M. Palomo, P. Bonomi, T. Bavaro, R. Fernandez-Lafuente, J. M. Guisan, M. Terreni, Tetrahedron 2008, 64, 9286-9292.

[30] C. Navuluri, D. Crich, Angew. Chem. Int. Ed. 2013, 52, 11339-11342. 
[31] S. Cai, B. Yu, Org. Lett. 2003, 5, 3827-3830.

[32] S. Sahabuddin, T. C. Chang, C.C. Lin, F. D. Jan, H. Y. Hsiao, K .T. Huang, J. H. Chen, J. C. Horng, J. A. Ho, Tetrahedron 2010, 66, 7510-7519.

[33] T. Bavaro, D. Ubiali, S. Brocca, S. Rocchietti, I. Nieto, M. Pregnolato, M. Lotti, M. Terreni, Biocatal. Biotransfor. 2010, 28, 108-116.

[34] P. Torres-Salas, A. Pedrali, T. Bavaro, S. Ambrosini, G. Marrubini, V. M. Pappalardo, G. Massolini, M. Terreni, D. Ubiali, Eur. J. Lipid Sci. Technol. 2014, 116, 1496-1504.

[35] A. Berkin, W. A. Szarek, R. Kisilevsky, Carbohydr. Res. 2002, 337, 37-44.

[36] Q. Abualassal, K. M. Al Azzam, J. A. Jilani, Biomed. Chromatogr. 2016, 30, 1416-1422.

[37] F. Yang, Y. Du, Carbohydr. Res. 2003, 338, 495-502.

[38] T. Peters, T. Weimar, Liebigs Annalen der Chemie 1991, 3, 237-242.

[39] V. Martichonok, G. M. Whitesides, J. Org. Chem. 1996, 61, 1702-1706.

[40] A. Lubineau, C. Augé, B. Bouxom, C. Gautheron, J. Carbohydr. Chem. 1992, 11, 59-70. 



\section{Captions}

Scheme 1. Regioselective hydrolysis of acetylated glucosamine and galactosamine derivatives 1-11 catalyzed by immobilized CRL and AXE (Table 1).

Scheme 2. (i) a) 14, Gal-TCA, $\mathrm{BF}_{3} \cdot \mathrm{Et}_{2} \mathrm{O}, \mathrm{CH}_{2} \mathrm{Cl}_{2}, \mathrm{~N}_{2}, 0{ }^{\circ} \mathrm{C},(\mathbf{2 3}, 68 \%$ yield; $\beta>95 \%)$; b) 14, ManTCA, $\mathrm{BF}_{3} \cdot \mathrm{Et}_{2} \mathrm{O}, \mathrm{CH}_{2} \mathrm{Cl}_{2}, \mathrm{~N}_{2}, 0^{\circ} \mathrm{C},(\mathbf{2 4}, 63 \%$ yield; $\alpha>95 \%$ ); (ii) a) $\mathrm{MeONa} / \mathrm{MeOH}$, r.t., $24 \mathrm{~h}, 50 \%$ yield IME-glycans; b) sodium tetraborate buffer, $\mathrm{pH} 9.5,25{ }^{\circ} \mathrm{C}$, molar ratio IME-glycan/ribonuclease A 100:1, 6 h; 23a yield 81\%; 24a yield >98\%; (iii) a) 14, sialyl xanthate, NIS, TfOH, $\mathrm{CH}_{3} \mathrm{CN} ;-40{ }^{\circ} \mathrm{C} ; 25$ yield 55\% ( $\alpha / \beta 3 / 2)$; b) 12, sialyl xanthate, $\mathrm{PhSCl}, \mathrm{AgOTf}, \mathrm{CH}_{3} \mathrm{CN}$ and $\mathrm{CH}_{2} \mathrm{Cl}_{2}(2 / 1), \mathrm{N}_{2} ;-68{ }^{\circ} \mathrm{C} ; 26$ yield 60\% ( $\alpha / \beta 2 / 1)$; c) 21, sialyl xanthate, $\mathrm{PhSCl}, \operatorname{AgOTf}, \mathrm{CH}_{3} \mathrm{CN}$ and $\mathrm{CH}_{2} \mathrm{Cl}_{2}(2 / 1), \mathrm{N}_{2} ;-68{ }^{\circ} \mathrm{C} ; 27$ yield $64 \%(\alpha / \beta 1 / 1)$.

Figure 1. MS spectra obtained in the glycosylation of RNase A with the glycans IME-23 and IME-24 to obtain neo-glycoproteins 23a (A) (average number of incorporated saccharides: 2.3) and 24a (B) (average number of incorporated saccharides: 4.1).

Scheme 3. (i) a) sialyl xanthate, $\mathrm{PhSCl}, \mathrm{AgOTf}, \mathrm{CH}_{3} \mathrm{CN}$ and $\mathrm{CH}_{2} \mathrm{Cl}_{2}(2 / 1), \mathrm{N}_{2},-68^{\circ} \mathrm{C} ; 28$ yield $70 \%$ (>98\%); 29 yield 64\% (>98\%); 30 yield 32\% (>98\%); 31 yield 30\% (>98\%); b) sialyl chloride, AgOTf, $\mathrm{CH}_{2} \mathrm{Cl}_{2}, \mathrm{~N}_{2},-40{ }^{\circ} \mathrm{C} ; 30$ yield $65 \%$ (95\%); 31 yield $70 \%$ (95\%). (ii) 28, $\mathrm{NH}_{2} \mathrm{CH}_{2} \mathrm{CH}_{2} \mathrm{NH}_{2}, \mathrm{AcOH}, \mathrm{THF}$, r.t., 3 h, 32 (75\% crude). (iii) 32, $\mathrm{CCl}_{3} \mathrm{CN}, \mathrm{DBU}, \mathrm{CH}_{2} \mathrm{Cl}_{2},-5{ }^{\circ} \mathrm{C}, 2 \mathrm{~h}, 33$ (60\%, $\alpha / \beta$ 4/1). (iv) 33, 3-Obenzoyl-azidosphingosine, $\quad \mathrm{BF}_{3} \cdot \mathrm{Et}_{2} \mathrm{O}, \quad \mathrm{CH}_{2} \mathrm{Cl}_{2}, \quad-30 \quad{ }^{\circ} \mathrm{C}, \quad 1.5 \quad \mathrm{~h}, \quad 34 \quad(61 \%)$. 


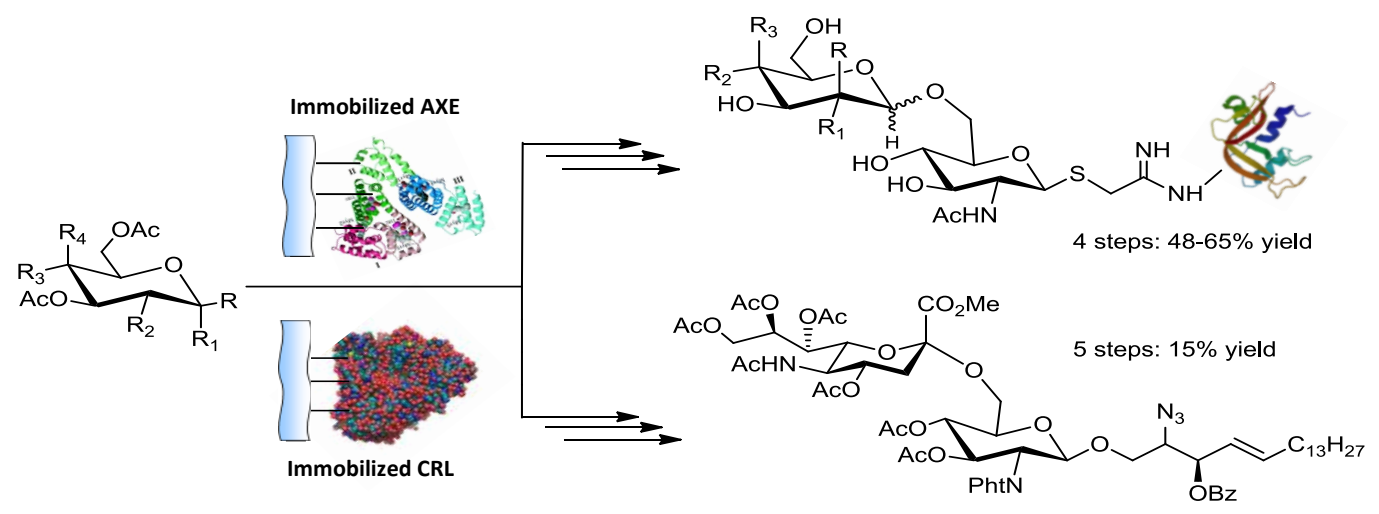

Chemoenzymatic approach, mediated by Acetyl xylan esterase (AXE) from Bacillus pumilus and Candida rugosa lipase (CRL), permits the concise synthesis of neo-glycoproteins and glycosphingolipids, respectively. 